\title{
Glycerol-Filled Silicone Adhesive Patches with Excellent Sun Protection
}

\author{
Yu, Liyun; Mazurek, Piotr; Madsen, Frederikke Bahrt; Skov, Anne Ladegaard
}

Published in:

Macromolecular Materials and Engineering

Link to article, DOI:

10.1002/mame.202000797

Publication date:

2021

Document Version

Early version, also known as pre-print

Link back to DTU Orbit

Citation (APA):

Yu, L., Mazurek, P., Madsen, F. B., \& Skov, A. L. (2021). Glycerol-Filled Silicone Adhesive Patches with Excellent Sun Protection. Macromolecular Materials and Engineering, 306(5).

https://doi.org/10.1002/mame.202000797

\section{General rights}

Copyright and moral rights for the publications made accessible in the public portal are retained by the authors and/or other copyright owners and it is a condition of accessing publications that users recognise and abide by the legal requirements associated with these rights.

- Users may download and print one copy of any publication from the public portal for the purpose of private study or research.

- You may not further distribute the material or use it for any profit-making activity or commercial gain

- You may freely distribute the URL identifying the publication in the public portal

If you believe that this document breaches copyright please contact us providing details, and we will remove access to the work immediately and investigate your claim 


\title{
Glycerol-filled silicone adhesive patches with excellent sun protection
}

\author{
Liyun Yu ${ }^{1}$, Piotr Mazurek ${ }^{1}$, Frederikke Bahrt Madsen², and Anne Ladegaard \\ Skov ${ }^{1,2}$ \\ ${ }^{1}$ Danish Polymer Centre, Department of Chemical and Biochemical Engineering, Building 227, Technical \\ University of Denmark, DK-2800 Kgs. Lyngby, Denmark \\ ${ }^{2}$ Glysious Polymer Technologies, Futurebox, Elektrovej 331, 2800 Kongens Lyngby, Denmark
}

\section{Abstract}

Numerous medical conditions such as cancer, eczema, moles and burns may leave patients with increased sensitivity to UV light. A UV-protective patch that provides a healing environment for sensitive or broken skin was therefore developed from two-phase glycerol-silicone adhesives. The adhesives were prepared using a simple processing method in which high shear forces mix glycerol and silicone prepolymers that are subsequently cured to form a stable, free-standing adhesive containing inherent discrete glycerol droplets. These materials are excellent candidates for wound care adhesives, since glycerol increases the silicone adhesives' water absorption while providing low peel forces and gentle adherence to the skin. Adhesives showed increased sun protection properties with increasing glycerol content. When $\mathrm{TiO}_{2}$, a well-known ingredient in sunscreen products, was added to the glycerol-filled silicone adhesives, the sun protection factor reached SPF 100 without compromising the mechanical or peel strength properties. Further, the sun protective properties of the $\mathrm{TiO}_{2}$-filled glycerol-silicone adhesives proved to be stable when exposed to $80 \%$ relative humidity for $20 \mathrm{~h}$ to simulate performance during typical usage.

\section{Introduction}

Sunlight, and in particular ultraviolet (UV) light, is known to cause severe damage to human skin. Damaging UV rays are divided into Ultraviolet $B$ (UVB) and Ultraviolet A (UVA), which range from 280-315 nm and 315$400 \mathrm{~nm}$, respectively. UVB rays penetrate the upper layer of the skin and cause sunburn, while UVA rays penetrate even further into the skin, causing damage such as cancer, wrinkles and sagging skin[1]. UV radiation is thus a major environmental risk factor for the development of melanomas and skin cancer[2][4]. However, skin cancers are highly preventable-e.g., by reducing sun exposure[5], [6].

The most commonly used sun protection for skin are sunscreens, which have been proven to reduce sunburns, skin ageing and skin cancer risk (melanoma and non-melanoma) through their ability to reflect, scatter and/or absorb UV light[7], [8]. Sunscreens exist in many types of formulations such as emulsions, gels, aerosols and sticks, and their active ingredients include inorganic and organic UV filters - which are the most commonly applied filter types[9] —as well as hybrid and botanical ingredients[10]. It was previously believed that inorganic filters (physical filters), which include titanium dioxide and zinc oxide particles, worked solely by reflecting and scattering the UV rays before they reach the skin. However, newer research suggests that inorganic filters provide UV protection primarily via semiconductor band gap mediated absorbance of UV 
photons[11]. Inorganic filters must be able to block UV light over the entire UVA/UVB range (290-400 nm), and their ability to reflect and scatter UV rays depends on their intrinsic refractive indexes, particle size and dispersion in the emulsion[7], [12].

Organic filters (chemical filters) such as avobenzone and octisalate absorb UV radiation energy due to their conjugated $\pi$ electron systems. When the number of conjugated double bonds in the molecule increases, the absorption maximum shifts to longer wavelengths and leads to a larger absorption cross-section, resulting in a stronger absorption[13]. Organic filters are classified as either UVA filters-such as benzophenones, anthranilates, and dinebenzoylmethanes-or UVB filters, such as salyciltates, cinnamates and PABA derivates. These filters are typically used in combination in order to provide broad UV protection and cover a wide range on the UV spectrum. Inorganic filters work immediately after application to the skin, whereas organic filters need time (typically $15-20 \mathrm{~min}$ ) to penetrate the skin and become effective.

Sunscreen efficiency is evaluated according to a sun protection factor (SPF) value that measures the amount of UV radiation it takes for sunscreen-protected skin to burn compared to unprotected skin. The amount of sunburn protection increases with increasing SPF value. SPF is thus a measure of how effectively a product shields one against short-wave sunburn-causing UVB radiation[14]. In the EU, there are four sunscreen labelling categories: Low protection (SPF 6, SPF 10), Medium Protection (SPF 15, SPF 20, SPF 25), High Protection (SPF 30, SPF 50) and Very High Protection (SPF 50+)[15].

SPF is defined as the ratio of the minimal erythemal (skin redness) dose on protected skin (MEDp) to the minimal erythemal dose on unprotected skin (MEDu)[16], [17], as shown in equation 1:

$S P F=\frac{\text { minimal erythemal dose on protected skin (MEDp) }}{\text { minimal erythemal dose on unprotected skin (MEDu) }}$

It is possible to determine SPF value using in vitro methods such as measuring the absorbance or transmittance of UV radiation of a sunscreen product solution, gel or film[16], [18]-[20]. One way to calculate SPF value is by using the very simple, so-called Mansur equation (equation 2) developed by Mansur et al.[21]:

$S P F=C F \times \sum_{290}^{320} E E(\lambda) \times I(\lambda) \times A b s(\lambda)$

where $\operatorname{EE}(\lambda)$ is the erythemal effect spectrum, I $(\lambda)$ is the solar intensity spectrum, Abs $(\lambda)$ is the absorbance of a given sunscreen product, and CF is the correction factor $(=10)$. The values of EE $(\lambda) \times I(\lambda)$ are constants originally determined by Sayre et al.[22].

Though sunscreens offer major health benefits, they can also lead to photoallergic dermatitis and environmental pollution; in addition, the discrepancy between the listed SPF value and the actual measured SPF value can cause problems[18], especially since the actual SPF value is dependent upon the amount of sunscreen applied to the skin[17]. Practical sunscreen efficiency is therefore hugely user-dependent, as it will provide insufficient protection if not applied uniformly and in sufficient amounts. The specific ingredients used, as well as their formulation, also significantly impact sunscreen efficiency [14].

A number of medical conditions and/or their treatments may result in increased sensitivity to UV light. These include radiation therapy for cancer, hydrocortisone treatment for children with eczema, and burns (either sunburn or another type). People with at-risk moles on UV exposed locations on the skin such as the face, scalp and hands can also suffer from such sensitivity. In such cases, patches offering sun protection while simultaneously providing a healing environment for the sensitive or broken skin would offer significant 
clinical benefits over traditional sunscreens or wound care dressings that lack inherent sun protection. In addition to guaranteeing that specific parts of the skin are protected from damaging UV rays until it is removed, a UV-protective patch would ensure that the user need not worry about reapplying sunscreen.

In this article, we describe the use of two-phase glycerol-silicone adhesives with and without inorganic UV filters, in the form of titanium dioxide particles, as sun protection patches. Glycerol-filled silicone elastomers were previously described by Mazurek et al.[23], [24]. These hybrid elastomers possess a bi-continuous or closed cell structure depending on the formulation, and can be processed as thin films, bulk elements or foams[25]. Stable glycerol-filled silicone adhesives are prepared using a simple processing method in which high shear forces are used to mix glycerol and silicone prepolymers. Curing of the silicone matrix subsequently creates stable, free-standing two-phase elastomers with inherent glycerol droplets. Such materials were recently used as wound care adhesives[26], and it was shown that the embedded glycerol produces adhesives that, because they adhere gently to the skin and can also be peeled off gently (i.e., without high peel forces), are ideal for use on sensitive or broken skin. The glycerol also increases both the water absorption and permeability of the silicone adhesives, making these materials excellent candidates for advanced wound care treatments. The two main constituents are silicone and glycerol, both of which are biocompatible and skin-friendly[27]. Silicone is widely used for implants and in skin care applications, while glycerol is one of the most common moisturizing ingredients in skin care[28], [29]. Silicone is also known to prevent and reduce scaring[30]. Since both components are some of the most commonly used materials in skin care and health technology, they have a proven track record for high skin tolerance and are, in this study, used in medical and pharmaceutical grade versions, which signifies that they are approved for such uses. In this paper, we show that these materials also possess UV protection properties and that depending on the formulation, storage and usage conditions, the glycerol-silicone patches have varying UV transmission properties.

\section{Materials and methods}

\section{Materials}

A commercial two-part, medical grade, biocompatible silicone adhesive system, SILPURAN ${ }^{\circledR} 2130$ A/B, was kindly provided by Wacker Chemie AG, Germany. Pharma-grade glycerol was provided from AppliChem $\mathrm{GmbH}$, Germany. Hydrophobic fumed titanium dioxide particles, AEROXIDE ${ }^{\circledR}$ TiO2 T 805, 20 nm primary particle size and coated with trimethyloctylsilane, were purchased from Evonik, Germany. Polyurethane (PU) backing, $30 \mu \mathrm{m}$, was obtained from Transcontinental Advanced Coatings, UK.

\section{Sample preparation}

The two-component silicone Silpuran was mixed in a 1:1 ratio with glycerol in varying amounts (by weight) depending on the desired concentration. For samples with particles $\left(\mathrm{TiO}_{2}\right)$ these were also mixed in by weight during the same step. Samples were mixed for 2 minutes at $3500 \mathrm{rpm}$ using a speedmixer (DAC 150.1 FVZ-K, Synergy Devices Ltd, UK) until uniform. Glycerol and particle concentrations are described using the abbreviation 'phr', which is defined as glycerol weight per hundred parts of silicone adhesive. For example, $60 \mathrm{phr}$ glycerol means that $60 \mathrm{~g}$ of glycerol was used per $100 \mathrm{~g}$ of silicone Silpuran base.

The sample mixture was then coated on a $30 \mu \mathrm{m}$ thick PU backing using a $200 \mu \mathrm{m}$ application cap (film applicator, 3540 bird, Elcometer, UK; automatic film coater, 4340, Elcometer, UK), leading to a final sample thickness of $\sim 100 \mu \mathrm{m}$ when fully cured. The samples were cured at $100^{\circ} \mathrm{C}$ for 1 hour. Photos of samples as patches with $60 \mathrm{phr}$ glycerol and $\mathrm{TiO}_{2}$ are shown in Supporting Information (SI, figure S1). 
Samples were tested after 3 different storing conditions to assess their properties: fresh after sample preparation and curing (start), after storing for $20 \mathrm{~h}$ in ambient conditions (ambient), and after $20 \mathrm{~h}$ at $80 \%$ relative humidity $(\mathrm{RH})$ and $25^{\circ} \mathrm{C}$ in a humidity chamber $(80 \% \mathrm{RH})$.

\section{Linear viscoelastic measurements}

Linear viscoelastic (LVE) properties of the glycerol-silicone adhesives were evaluated on a Discovery HR-1 hybrid rheometer (TA Instruments, US) set to a controlled strain mode of $2 \%$, which was ensured to be within the linear viscoelastic regime. Measurements were performed in the frequency range of $50-0.01 \mathrm{~Hz}$, with a parallel plate geometry of $20 \mathrm{~mm}$. The samples were approximately $5 \mathrm{~mm}$ thick; exact thicknesses were measured by applying a small normal force from the upper plate in the rheometer, which further ensured that there were no-slip conditions. 3 measurements were performed on each sample.

\section{Peel tests on stainless steel plate}

$180^{\circ}$ peel force tests were performed following the ASTM D3330 standards for pressure sensitive adhesives. Samples were coated and cured on polyethylene terephthalate (PET) backing (75 $\mu \mathrm{m}$ thick, HOSTAPHAN ${ }^{\circledR}$, Mitsubishi Polyester Film). The $\sim 100 \mu \mathrm{m}$ thick samples were cut in $25 \mathrm{~mm} \times 120 \mathrm{~mm}$ rectangles and manually placed onto a stainless-steel plate; a $2 \mathrm{~kg}$ weight roller was then used to ensure proper attachment and minimize air inclusion between sample and substrate. Peel tests were performed using an Instron 3340 (Instron, US) universal testing machine equipped with a $50 \mathrm{~N}$ load cell. Peel rate and peel angle were set to 5 $\mathrm{mm} / \mathrm{s}$ and $180^{\circ}$, respectively. 3 measurements were performed for each composition, and the results were averaged.

\section{Transmission tests}

The samples were tested on a POLARstar Omega (BMG LABTECH, Germany) UV/vis spectrometer at wavelengths ranging from 220 to $1000 \mathrm{~nm}$. 6 measurements were taken for each sample. Light transmission was then calculated from the measured absorbance.

\section{Scanning electron microscopy (SEM) analysis}

The cross-sectional morphology of glycerol-silicone adhesive patches was investigated with an FEI Quanta 200 ESEM scanning electron microscope, equipped with a field emission gun. The patches were cut by a sharp blade and subsequently coated on $5 \mathrm{~nm}$-thick gold by means of a sputter coater (Q150T ES, Quorum Technologies, UK) under vacuum condition and a current of $40 \mathrm{~mA}$ for 10 seconds. The cross-section was detected with a secondary electron detector (SE) for an incident electron beam of spot 3 accelerated to 15 keV.

\section{Optical microscopy images}

The morphology of the samples was determined using an optical microscope, model DMLB from Leica Microsystems.

\section{Results and discussion}

Glycerol-filled silicone adhesives with varying glycerol contents were prepared by applying high shear forces to a glycerol and silicone premix mixture. Curing produced approximately $100 \mu \mathrm{m}$ thick free-standing film 
samples in which silicone constitutes the continuous phase within which glycerol exists as dispersed droplets. Morphology images of similar formulations can be found in previous publications [23], [26]. In general, it was shown that, for particle-free glycerol-silicone adhesives, higher glycerol concentration led to thinner spacing between glycerol droplets and larger glycerol droplet diameter[26]; for adhesives with inorganic particles in the silicone phase, on the other hand, the glycerol droplet diameter remained the same with increasing glycerol-content due to the stabilizing effect of the particles[23]. Glycerol-silicone adhesives show increased water absorption compared to pure silicone adhesives due to the permeable nature of silicone combined with the hygroscopic nature of glycerol owing to the three hydroxyl groups present on the glycerol molecule[23]. This enhanced absorptive capacity is favorable for skin care adhesives and wound dressings, as it avoids maceration of the skin; however, increased water uptake may affect the mechanical and sun protection properties of the patches during wear. The glycerol-silicone samples tested here were therefore exposed to different environments after preparation in order to determine the adhesives' performance as sun protection patches under simulated storage and usage conditions. First, samples were measured and analyzed directly after preparation and curing (start). Second, samples were measured after $20 \mathrm{~h}$ in ambient conditions (ambient) to evaluate the properties of the patches during and after storing. Finally, samples were measured after storing for $20 \mathrm{~h}$ at $80 \%$ relative humidity $(\mathrm{RH})$ in a humidity chamber $(80 \% \mathrm{RH})$ to elucidate sun protection performance during wear, when the skin is moist due to perspiration or wound exudate.

\section{Linear viscoelastic properties of glycerol-filled silicone adhesives}

The viscoelastic properties of the glycerol-filled silicone adhesives were investigated by determining their shear storage $\left(G^{\prime}\right)$ and shear loss moduli $\left(G^{\prime \prime}\right)$. The results of $G^{\prime}$ and dissipation factors ( $\left.\tan \delta=G^{\prime} / G^{\prime \prime}\right)$ as a function of frequency are shown in Figure 1, and the resulting shear storage moduli and losses at $1 \mathrm{~Hz}$ are summarized in Table 1. It is evident from Figure 1 and Table 1 that the storage modulus, perhaps counterintuitively, increases along with increasing liquid glycerol content. Further, $\tan \delta$ decreases across the entire frequency range in line with increasing glycerol content. In other words, higher liquid content results in a more solid-like material. This type of behavior has been previously reported for glycerol-filled silicone adhesives[26], [31], and these results suggest that increased glycerol loading leads to an increased elastic rather than viscous response. This elasticity arises not only from the cross-linked silicone network, but also from the interfacial energies that contribute more and more to elasticity when glycerol loading is increased. Thus, higher glycerol content produces more glycerol droplets, which in turn leads to a higher interfacial energy-i.e., a stiffening effect-while the elastic contribution from the polymer network decreases due to volumetric dilution. A more detailed theoretical explanation on this phenomenon can be found in references [31], [32]. 

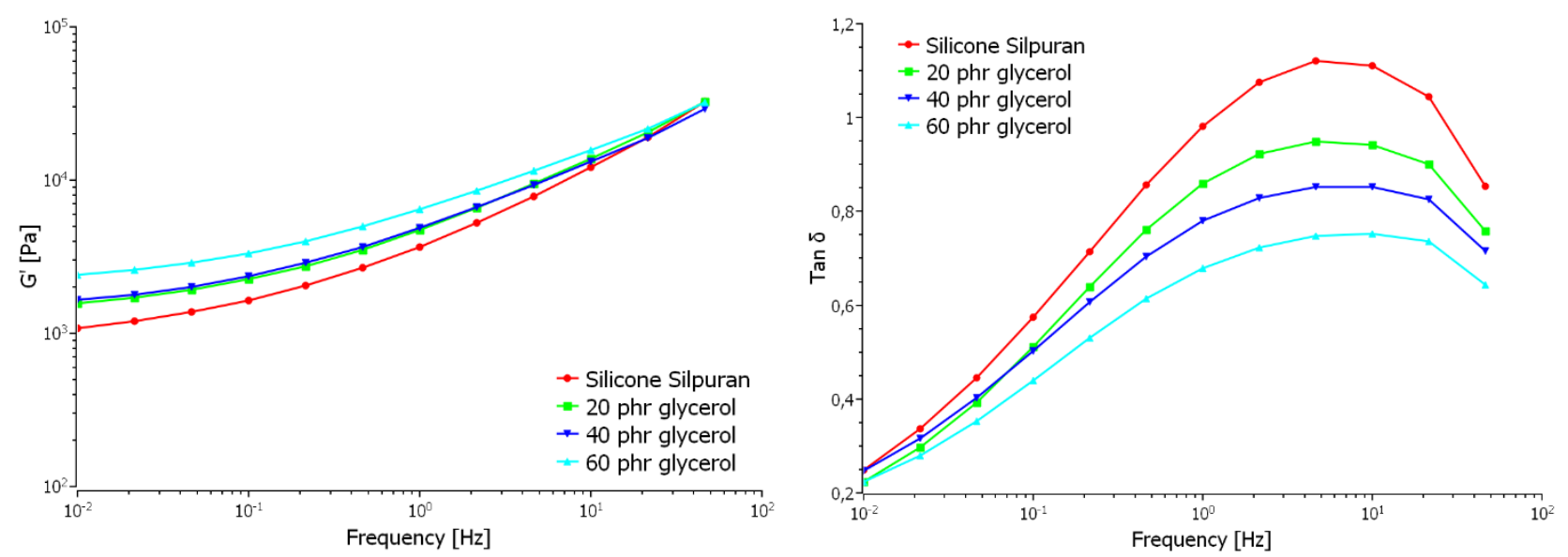

Figure 1: Linear viscoelastic properties of glycerol-filled silicone adhesives with varying glycerol contents at room temperature.

Table 1: Storage moduli $\left(G^{\prime}\right)$, dissipation factor (tan $\delta$ ) and peel force for glycerol-filled silicone with varying glycerol contents.

\begin{tabular}{|c|c|c|c|c|}
\hline Sample & $\begin{array}{c}\text { Time of } \\
\text { measurement }\end{array}$ & G' @ 1 Hz [kPa] & Tan $\delta @ 1 ~ H z$ & $\begin{array}{l}\text { Peel force } \\
{[\mathrm{N} / 25 \mathrm{~mm}]}\end{array}$ \\
\hline \multirow{3}{*}{$\begin{array}{l}\text { Silicone } \\
\text { Silpuran } \\
\text { (Ref.) }\end{array}$} & $\begin{array}{l}\text { Immediately after } \\
\text { curing (start) }\end{array}$ & 3.66 & 0.98 & $0.62 \pm 0.03$ \\
\hline & $\begin{array}{l}20 \mathrm{~h} @ \text { ambient } \\
\text { conditions (ambient) }\end{array}$ & 3.75 & 0.97 & $0.54 \pm 0.01$ \\
\hline & $\begin{array}{l}20 \mathrm{~h} @ 80 \% \mathrm{RH}(80 \% \\
\mathrm{RH})\end{array}$ & 3.79 & 0.96 & $0.28 \pm 0.01$ \\
\hline \multirow{3}{*}{$\begin{array}{l}20 \mathrm{phr} \\
\text { glycerol } \\
\text { (G20) }\end{array}$} & $\begin{array}{l}\text { Immediately after } \\
\text { curing (start) }\end{array}$ & 4.71 & 0.86 & $0.55 \pm 0.02$ \\
\hline & $\begin{array}{l}20 \mathrm{~h} @ \text { ambient } \\
\text { conditions (ambient) }\end{array}$ & 4.74 & 0.85 & $0.51 \pm 0.02$ \\
\hline & $\begin{array}{l}20 \mathrm{~h} @ 80 \% \mathrm{RH}(80 \% \\
\mathrm{RH})\end{array}$ & 4.70 & 0.83 & $0.32 \pm 0.02$ \\
\hline \multirow{3}{*}{$\begin{array}{l}40 \text { phr } \\
\text { glycerol } \\
\text { (G40) }\end{array}$} & $\begin{array}{l}\text { Immediately after } \\
\text { curing (start) }\end{array}$ & 4.88 & 0.78 & $0.47 \pm 0.03$ \\
\hline & $\begin{array}{l}20 \mathrm{~h} @ \text { ambient } \\
\text { conditions (ambient) }\end{array}$ & 5.38 & 0.76 & $0.43 \pm 0.01$ \\
\hline & $\begin{array}{l}20 \mathrm{~h} @ 80 \% \mathrm{RH}(80 \% \\
\mathrm{RH})\end{array}$ & 5.20 & 0.75 & $0.32 \pm 0.03$ \\
\hline \multirow{3}{*}{$\begin{array}{l}60 \text { phr } \\
\text { glycerol } \\
\text { (G60) }\end{array}$} & $\begin{array}{l}\text { Immediately after } \\
\text { curing (start) }\end{array}$ & 6.42 & 0.68 & $0.45 \pm 0.01$ \\
\hline & $\begin{array}{l}20 \mathrm{~h} @ \text { ambient } \\
\text { conditions (ambient) }\end{array}$ & 6.43 & 0.67 & $0.41 \pm 0.02$ \\
\hline & $\begin{array}{l}20 \mathrm{~h} @ 80 \% \mathrm{RH}(80 \% \\
\mathrm{RH})\end{array}$ & 6.23 & 0.65 & $0.30 \pm 0.01$ \\
\hline
\end{tabular}

Linear viscoelastic measurement results are shown in Figure 2 for the silicone reference as well as the $60 \mathrm{phr}$ glycerol sample, and results for the reference and all samples are summarized in Table 1. Plots for the 20 and $40 \mathrm{phr}$ glycerol samples can be found in the Supporting Information (SI, Figure S2). The data from Figure 2 and Table 1 show that storage moduli $\left(G^{\prime}\right)$ are not significantly affected by different storing conditions, and no clear trend is observable. The dissipations factors, $\tan \delta$, are seen to slightly decrease for all samples, albeit in the same range as for the pure silicone reference. This indicates that the glycerol-filled patches maintain mechanical integrity and stability during storage and wear conditions. 

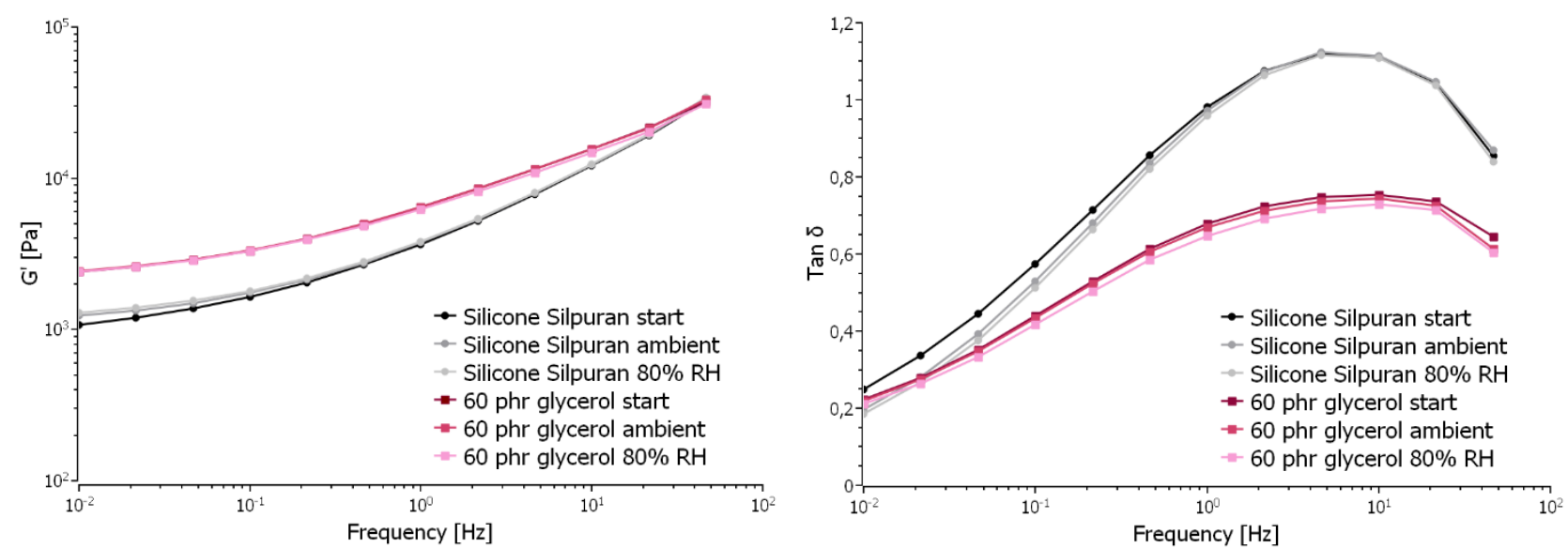

Figure 2: Linear viscoelastic measurements of glycerol-filled silicone adhesives with 0 and $60 \mathrm{phr}$ glycerol before and after storing at ambient and high humidity conditions (20 h in ambient conditions and $20 \mathrm{~h}$ in $80 \% \mathrm{RH}$ ).

\section{Peel force measurements of glycerol-filled silicone adhesive patches with varying glycerol content}

The peel forces of the glycerol-filled silicone adhesives were measured from stainless steel plates, and the results are summarized in Figure 3 and Table 1 . As these results clearly show, peel force decreases with increasing glycerol content-from $0.62 \mathrm{~N}$ for the Silicone Silpuran reference to $0.45 \mathrm{~N}$ for a 60 phr glycerol sample. The peel force is dependent on the thickness of the adhesive[33] and, since the presence of glycerol droplets lowers the true thickness of the silicone part in the adhesive, a drop in peel force is observed with increasing glycerol content, as the thickness of the adhesive is no longer the thickness of the film, but rather the average distance between the discrete glycerol droplets. The peel force of the Silpuran 2130 reference/base is relatively low to begin with, since it is a low adhesion medical grade silicone developed for wound care and skin adhesives[34].

Storage conditions' effect on peel force was also measured, and is likewise shown in Figure 3 and summarized in Table 1. Peel force decreases only very slightly after $20 \mathrm{~h}$ in ambient conditions, whereas a significant drop in peel force is seen for all samples after storing for $20 \mathrm{~h}$ at $80 \% \mathrm{RH}$. This suggests that the glycerol-filled silicone patches remain stable under typical storage conditions, but that the properties of the adhesive change at $80 \% \mathrm{RH}$ due to water uptake. The drop in peel force for both pure silicone and glycerol-filled silicone samples may be due to the polar nature of water molecules, which causes swelling that disrupts the secondary bonds on the interface, thus lowering the adhesive strength[35].

The drop in peel force after $20 \mathrm{~h}$ in $80 \% \mathrm{RH}$ is lower for samples with higher glycerol content up to $40 \mathrm{phr}$, after which it remains similar for the $60 \mathrm{phr}$ glycerol sample. Thus, while the pure silicone Silpuran experiences a drop in peel force of over $50 \%$ after $20 \mathrm{~h}$ in $80 \% \mathrm{RH}$, the 40 and $60 \mathrm{phr}$ glycerol-filled silicone adhesive samples only experience a roughly $30 \%$ drop in peel force over this same period. This may be due to the fact that the glycerol droplets in the silicone adhesives are able to absorb and contain water, thereby making the surface of the glycerol-silicone adhesive less affected by the moisture compared to the pure silicone adhesive.

A drop in peel force during wear is considered acceptable, since this means that the patch will be easier to peel off after wear. The peel forces of the glycerol-containing samples after exposure to high $\mathrm{RH}$ is considered to be high enough to still provide sufficient adhesion during the expected wear time when compared to peel forces of commercially available silicone adhesives[36]. 


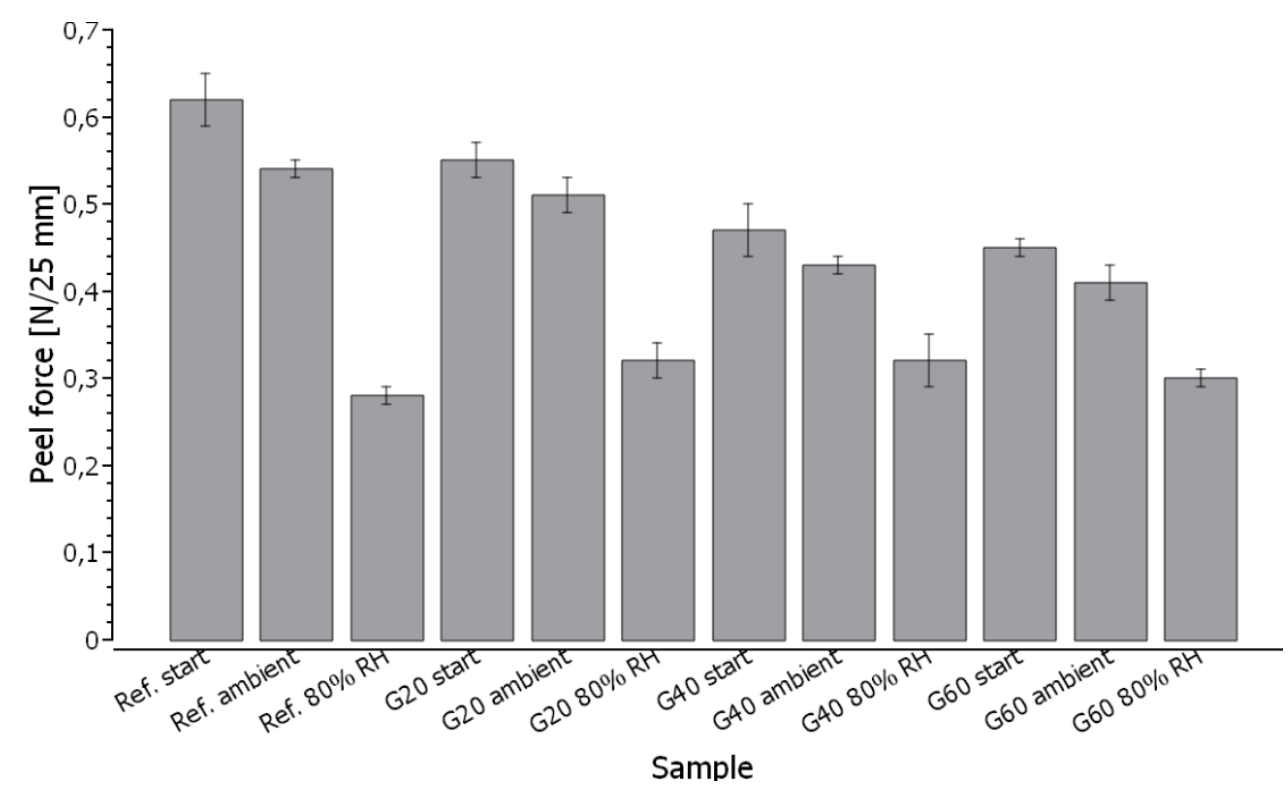

Figure 3: Peel forces of glycerol-filled silicone adhesives with varying glycerol loading.

\section{Transmission and sun protection factor of glycerol-filled silicone adhesives}

The light transmission of glycerol-filled silicone adhesive as a function of wavelength is shown in Figure 4, with the transmission of PU backing also shown as a reference.

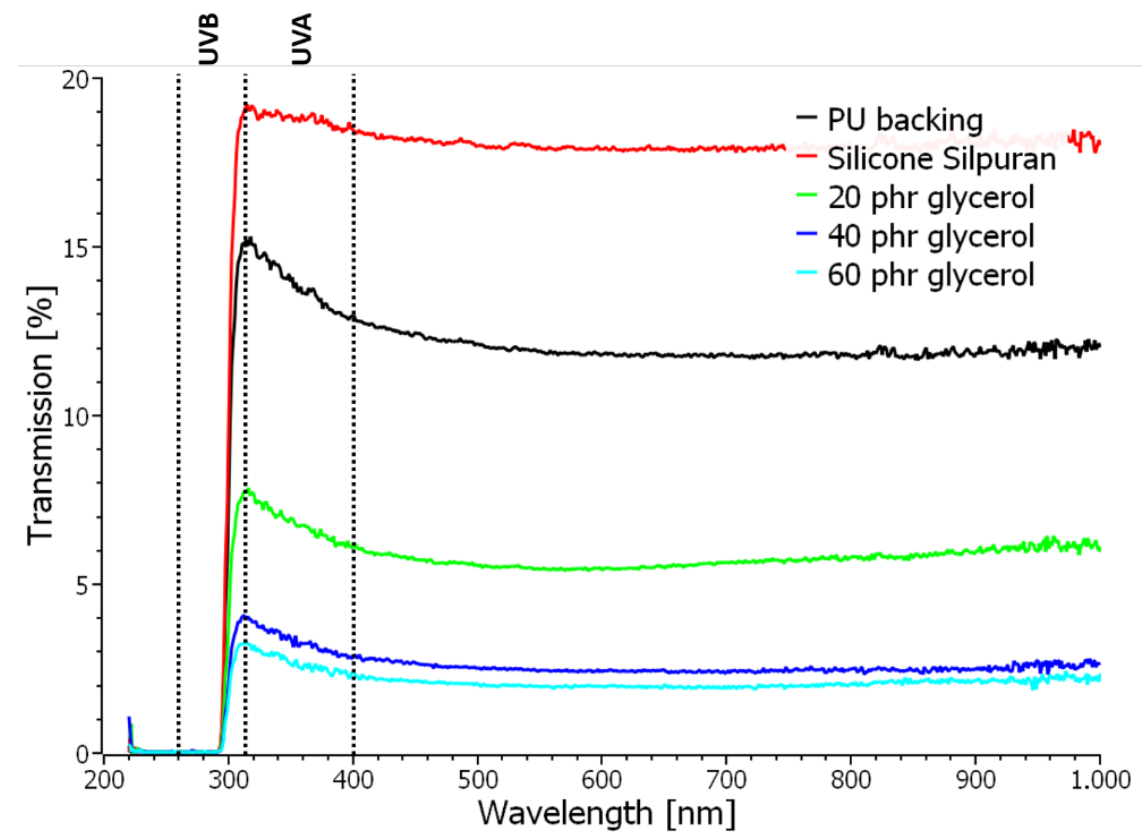

Figure 4: Transmission (\%) as a function of wavelength ( $\mathrm{nm}$ ) for glycerol-filled silicone adhesives (with varied glycerol content from 20-60 phr) as well as PU backing (30 $\mathrm{mm}$ ) and silicone Silpuran reference (on PU backing).

The PU backing ( $30 \mu \mathrm{m}$ thin) blocks practically all transmission of light below $295 \mathrm{~nm}$, which corresponds to shorter wavelength UVB rays. Interestingly, light transmission increases after the addition of pure silicone adhesive to the PU backing, likely due to the silicone 'smoothing out' the surface roughness of the PU 
backing, thereby making the resulting laminate more transparent. After addition of glycerol to the silicone adhesive, light transmission decreases with increasing glycerol content. The resulting transmission values at selected wavelengths in the UVB and UVA region are listed in 
Table 2. As the listed values show, transmission decreases to as low as $\sim 2 \%$ for the $60 \mathrm{phr}$ glycerol sample, and while the decrease in transmission between $40 \mathrm{phr}$ and $60 \mathrm{phr}$ samples may not appear qualitatively significant (see Figure 4 ), there is actually a $20 \%$ decrease in transmission that occurs.

SPF is a quantitative measure of the effectiveness of a sunscreen film and can therefore also be used to measure the efficacy of the prepared glycerol-silicone sun protection patches. At a given wavelength, the inverse of transmission, $T$, equals the factor of attenuation of the corresponding radiation; thus, $1 / T(\lambda)$ can be said to be equal to $\operatorname{SPF}(\lambda)$ : i.e., a monochromatic protection factor[22], [37]. In order to determine effectiveness over a broader spectral range, the Mansur equation (equation 2) can be used. The results of these calculations are shown in 
Table 2 (the correction factor, CF, was normalized by the maximum absorbance value of the spectrometer (see further explanation in Supporting Information and in SI, Figure S8)). As expected, the SPF values are seen to increase with increasing glycerol content, reaching SPF 49 for the $60 \mathrm{phr}$ sample. 
Table 2: Overview of the recorded transmission data for glycerol-filled silicone samples on PU backing at various wavelengths as well as the corresponding calculated SPF value.

\begin{tabular}{|c|c|c|c|c|c|c|c|}
\hline \multirow[b]{2}{*}{ Sample } & \multirow[b]{2}{*}{$\begin{array}{c}\text { Time of } \\
\text { measurement }\end{array}$} & \multicolumn{5}{|c|}{ Transmission (\%) } & \multirow[b]{2}{*}{$\begin{array}{l}\text { Calculated } \\
\text { SPF-value }\end{array}$} \\
\hline & & $\begin{array}{c}280 \mathrm{~nm} \\
\left(T_{\min }\right)\end{array}$ & $300 \mathrm{~nm}$ & $\begin{array}{c}315 \mathrm{~nm} \\
\left(T_{\max }\right)\end{array}$ & $350 \mathrm{~nm}$ & $400 \mathrm{~nm}$ & \\
\hline \multirow{3}{*}{ PU backing } & $\begin{array}{c}\text { Immediately after } \\
\text { curing (start) }\end{array}$ & 0,04 & 7,40 & 15,1 & 14,0 & 13,0 & 31 \\
\hline & $\begin{array}{c}20 \mathrm{~h} @ \text { ambient } \\
\text { conditions } \\
\text { (ambient) }\end{array}$ & 0,03 & 7,21 & 14,9 & 14,0 & 12,8 & 31 \\
\hline & $\begin{array}{c}20 \text { h @ 80\% RH } \\
(80 \% \mathrm{RH})\end{array}$ & 0,03 & 7,30 & 15,3 & 14,1 & 13,1 & 31 \\
\hline \multirow{3}{*}{$\begin{array}{l}\text { Silicone } \\
\text { Silpuran } \\
\text { (ref.) }\end{array}$} & $\begin{array}{c}\text { Immediately after } \\
\text { curing (start) }\end{array}$ & 0,03 & 9,48 & 19,2 & 18,9 & 18,5 & 26 \\
\hline & $\begin{array}{c}20 \text { h @ ambient } \\
\text { conditions } \\
\text { (ambient) }\end{array}$ & 0,03 & 10,8 & 21,8 & 21,7 & 20,8 & 26 \\
\hline & $\begin{array}{c}20 \text { h @ 80\% RH } \\
(80 \% \mathrm{RH})\end{array}$ & 0,03 & 10,8 & 22,4 & 22,0 & 21,4 & 26 \\
\hline \multirow{3}{*}{$\begin{array}{l}20 \text { phr } \\
\text { glycerol } \\
\text { (G20) }\end{array}$} & $\begin{array}{c}\text { Immediately after } \\
\text { curing (start) }\end{array}$ & 0,03 & 3,79 & 7,78 & 6,96 & 6,06 & 40 \\
\hline & $\begin{array}{c}20 \mathrm{~h} @ \text { ambient } \\
\text { conditions } \\
\text { (ambient) }\end{array}$ & 0,03 & 3,99 & 7,95 & 6,85 & 6,25 & 37 \\
\hline & $\begin{array}{c}20 \mathrm{~h} @ 80 \% \mathrm{RH} \\
(80 \% \mathrm{RH})\end{array}$ & 0,03 & 6,27 & 12,3 & 11,6 & 10,7 & 31 \\
\hline \multirow{3}{*}{$\begin{array}{l}40 \text { phr } \\
\text { glycerol } \\
\text { (G40) }\end{array}$} & $\begin{array}{c}\text { Immediately after } \\
\text { curing (start) } \\
\end{array}$ & 0,03 & 2,04 & 4,00 & 3,42 & 2,88 & 46 \\
\hline & $\begin{array}{c}20 \text { h @ ambient } \\
\text { conditions } \\
\text { (ambient) }\end{array}$ & 0,03 & 2,74 & 5,41 & 4,41 & 3,83 & 43 \\
\hline & $\begin{array}{c}20 \mathrm{~h} @ 80 \% \mathrm{RH} \\
(80 \% \mathrm{RH})\end{array}$ & 0,03 & 5,02 & 10,1 & 8,86 & 7,84 & 34 \\
\hline \multirow{3}{*}{$\begin{array}{l}60 \text { phr } \\
\text { glycerol } \\
\text { (G60) }\end{array}$} & $\begin{array}{c}\text { Immediately after } \\
\text { curing (start) }\end{array}$ & 0,04 & 1,65 & 3,27 & 2,68 & 2,35 & 49 \\
\hline & $\begin{array}{c}20 \mathrm{~h} @ \text { ambient } \\
\text { conditions } \\
\text { (ambient) }\end{array}$ & 0,03 & 1,70 & 3,27 & 2,76 & 2,25 & 47 \\
\hline & $\begin{array}{c}20 \mathrm{~h} @ 80 \% \mathrm{RH} \\
(80 \% \mathrm{RH})\end{array}$ & 0,03 & 4,50 & 8,86 & 7,59 & 7,01 & 37 \\
\hline
\end{tabular}

The transmission as a function of wavelength at different storing conditions is shown in Figure 5 for pure silicone Silpuran and the silicone adhesive with $60 \mathrm{phr}$ glycerol. The transmission spectra for PU backing and both 20 and $40 \mathrm{phr}$ samples can be found in the Supporting Information (SI, Figure S3-S7). The observed transmission values are also summarized in 
Table 2.

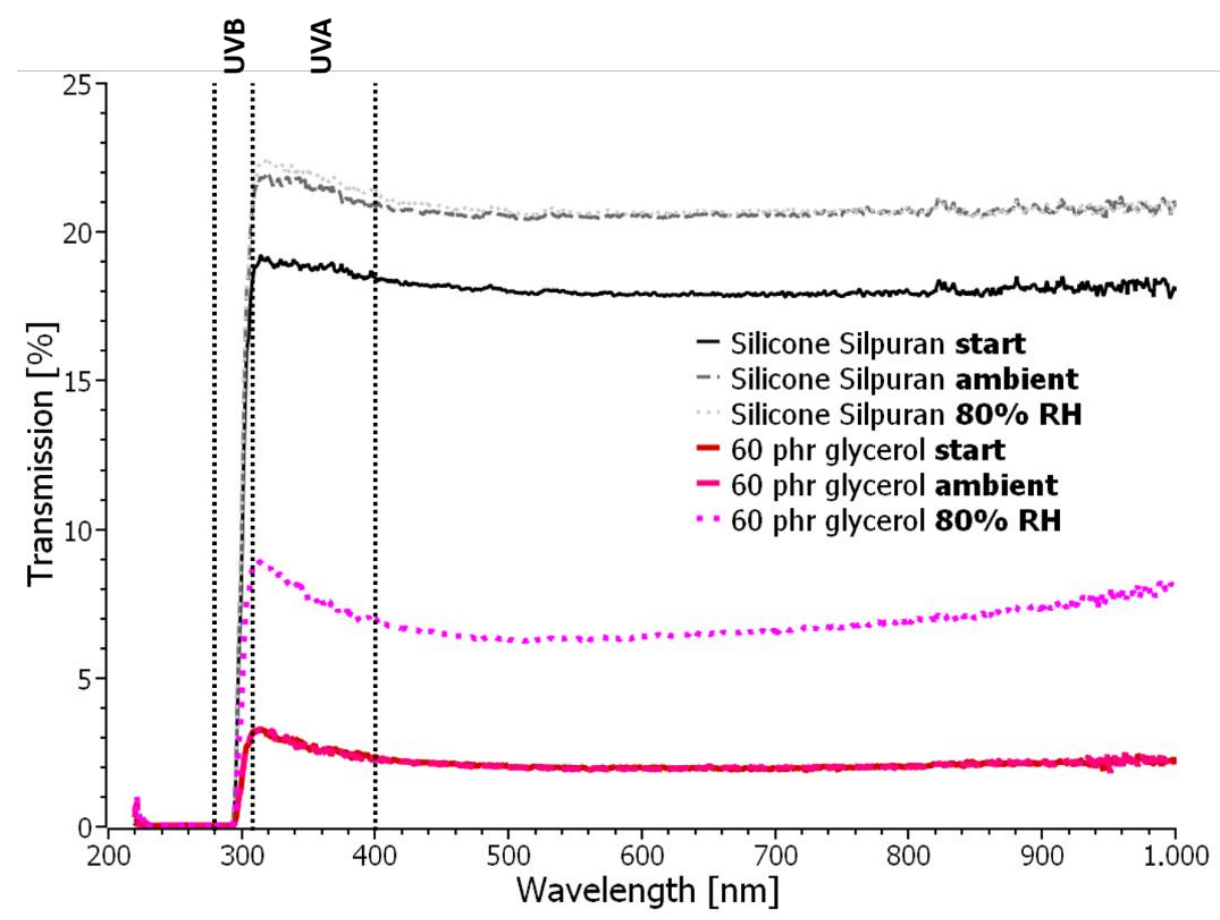

Figure 5: Transmission (\%) as a function of wavelength ( $\mathrm{nm}$ ) for glycerol-filled silicone adhesive after different storing conditions.

The transmission data shows that PU backing is not affected by moisture after storing at either ambient or high humidity conditions. Pure silicone Silpuran, on the other hand, is affected by moisture after storing at both conditions. Although silicone is hydrophobic, it is permeable to water vapor; water lowers the refractive index of the silicone, thus increasing light transmission. After addition of glycerol to the silicone, the adhesives were seen to remain stable after storing at ambient conditions, with hardly any increase in transmission observed for these samples. However, all glycerol-filled samples were affected by storing at high humidity, with light transmission approximately doubling for all samples after $20 \mathrm{~h}$ storage at $80 \% \mathrm{RH}$. This corresponds to a decrease in sun protection factor of around 40-50 to 30-40, depending on the glycerol content. This decrease is the result of water uptake by the glycerol droplets, which lowers the refractive index. The refractive indexes of the silicone and the glycerol/water thus eventually approach the same value, at which point light is able to pass through the samples without being reflected or refracted.

Since the humidity chamber mimics the environment that an adhesive on skin (broken or not) may experience depending on the level of exudate or perspiration it is exposed to, the humidity tests are a good indicator of the sun protection patches' real performance. Because transmission was not affected by storing at ambient conditions, it is safe to assume the patches' properties will not change between preparation and usage/wear. However, increased transmission and concomitantly decreased sun protection during wear may be problematic. Further optimization of the material compositions was therefore performed to eliminate the patches' sensitivity to the humidity resulting from, e.g., sweat or swimming.

\section{Effect of added particles}

In order to improve transmission and SPF during both storage and wear, hydrophobic titanium dioxide $\left(\mathrm{TiO}_{2}\right)$ was added to the formulation containing $60 \mathrm{phr}$ glycerol, which offered the lowest light transmission among the tested samples. $\mathrm{TiO}_{2}$ is a well-known and commonly used ingredient in sunscreen lotions due to its ability 
to absorb almost the entire UV spectrum. It is furthermore one of the most used ingredients in cosmetics and creams and is considered safe for topical application since it does not penetrate beyond the outer layer of the epidermis (stratum corneum) either in broken or unbroken skin. Moreover, according to the Scientific Committee on Consumer Safety, $\mathrm{TiO}_{2}$ poses no risk when applied to the skin in concentrations up to $25 \%$ and is considered a non-sensitizer and non-irritant[38]. $\mathrm{TiO}_{2}$ further acts as a mechanically reinforcing particle in the silicone adhesive, providing a durable and stable glycerol-filled silicone patch. SEM and optical microscopy images of glycerol-silicone adhesives containing $\mathrm{TiO}_{2}$ are shown in the supporting information (SI, figure S9 to S14) to illustrate the cross-sectional morphology and morphology, respectively.

\section{Linear viscoelastic properties of glycerol-filled silicone adhesives with $\mathrm{TiO}_{2}$}

The viscoelastic properties of glycerol-filled silicone adhesives with $\mathrm{TiO}_{2}$ are shown in Figure 6 and summarized in Table 3. The storage modulus of $60 \mathrm{phr}$ glycerol-filled silicone with both 1 and $2 \mathrm{phr} \mathrm{TiO}_{2}$ is only slightly lower and thus comparable to that of the $60 \mathrm{phr}$ glycerol-silicone adhesive without particles

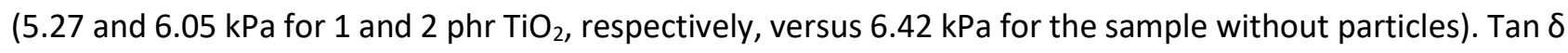
is also in the same range as for the unfilled sample. This is due to the hydrophobic $\mathrm{TiO}_{2}$ being well-dispersed in the hydrophobic silicone phase, but also partly dispersed in the glycerol phase (most likely due to nonideal hydrophobization).

As Figure 6 shows, the effects of different storing and moisture conditions on $\mathrm{TiO}_{2}$-filled samples are in the same range as for samples without $\mathrm{TiO}_{2}$, indicating that $\mathrm{TiO}_{2}$ does not negatively impact the mechanical properties of the samples during storage and wear conditions.
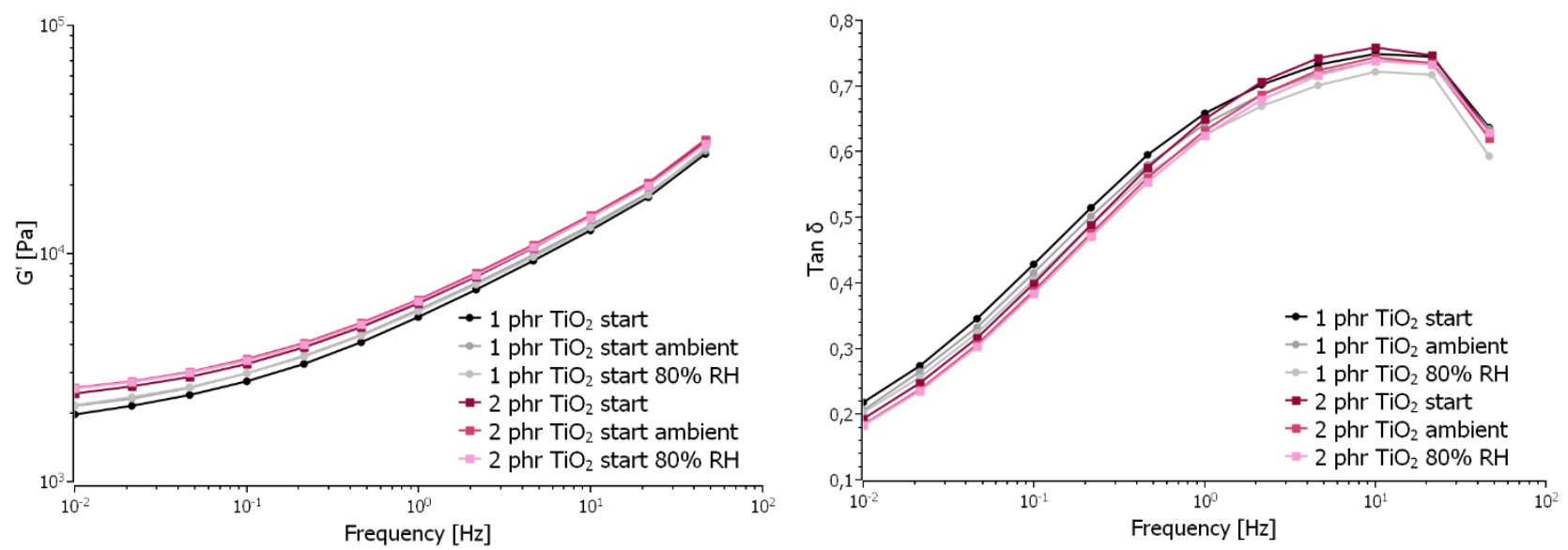

Figure 6: Linear viscoelastic properties of glycerol-filled silicone adhesives with $60 \mathrm{phr}$ glycerol and 1 and 2 phr TiO $\mathrm{O}_{2}$,respectively, before and after storing at ambient and high humidity conditions.

\section{Peel force measurements of glycerol-filled silicone adhesive patches with $\mathrm{TiO}_{2}$}

Table 3 summarizes the peel forces of $60 \mathrm{phr}$ silicone adhesives with 1 and $2 \mathrm{phr} \mathrm{TiO}_{2}$, respectively, and shows that peel force (start) is only negligibly affected by the addition of $\mathrm{TiO}_{2}$. This is most likely due to the low surface energy of silicone, which tends to migrate to the surface of the mixture. The surface of the adhesive therefore consists of silicone, regardless of $\mathrm{TiO}_{2}$-content.

The effect of storage conditions on the peel force of $\mathrm{TiO}_{2}$-filled samples was also measured and is likewise shown in Table 3. After storage at both ambient and high humidity conditions, the peel force can be seen to 
follow the same trend observed for the unfilled samples: storing at ambient conditions does not affect the peel force, but storing at $80 \% \mathrm{RH}$ for $20 \mathrm{~h}$ leads to a significant drop in peel force. Adding particles therefore does not alter the peel properties of the glycerol-silicone adhesives.

Table 3: Storage moduli ( $\left.G^{\prime}\right)$, dissipation factor (tan $\left.\delta\right)$ and peel force for glycerol-filled silicone with 60 phr glycerol and 1 and 2 phr $\mathrm{TiO}_{2}$, respectively.

\begin{tabular}{|c|c|c|c|c|}
\hline Sample & $\begin{array}{l}\text { Time of } \\
\text { measurement }\end{array}$ & G' @ 1 Hz [kPa] & Tan $\delta @ 1$ Hz & $\begin{array}{l}\text { Peel force } \\
\text { [N/25mm] }\end{array}$ \\
\hline \multirow{3}{*}{$\begin{array}{l}\text { 60phr glycerol } \\
+1 \mathrm{phr} \mathrm{TiO}_{2}\end{array}$} & $\begin{array}{l}\text { Immediately after } \\
\text { curing (start) }\end{array}$ & 5.27 & 0.66 & $0.48 \pm 0.02$ \\
\hline & $\begin{array}{l}20 \mathrm{~h} @ \text { ambient } \\
\text { conditions (ambient) }\end{array}$ & 5.64 & 0.64 & $0.42 \pm 0.02$ \\
\hline & $\begin{array}{l}20 \mathrm{~h} @ 80 \% \mathrm{RH}(80 \% \\
\mathrm{RH})\end{array}$ & 5.58 & 0.63 & $0.30 \pm 0.02$ \\
\hline \multirow{3}{*}{ 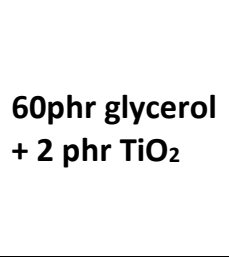 } & $\begin{array}{l}\text { Immediately after } \\
\text { curing (start) }\end{array}$ & 6.05 & 0.65 & $0.45 \pm 0.02$ \\
\hline & $\begin{array}{l}20 \mathrm{~h} @ \text { ambient } \\
\text { conditions (ambient) }\end{array}$ & 6.29 & 0.63 & $0.42 \pm 0.02$ \\
\hline & $\begin{array}{l}20 \mathrm{~h} @ 80 \% \mathrm{RH}(80 \% \\
\mathrm{RH})\end{array}$ & 6.19 & 0.62 & $0.30 \pm 0.02$ \\
\hline
\end{tabular}

\section{Transmission and sun protection factor of glycerol-filled silicone adhesive patches with $\mathrm{TiO}_{2}$}

The transmission spectra for $\mathrm{TiO}_{2}$-filled silicone adhesives are shown in Figure 7 and summarized in Table 4. The data clearly shows that adding $\mathrm{TiO}_{2}$ to the glycerol-filled silicone adhesives decreases light transmission substantially. After addition of $2 \mathrm{phr} \mathrm{TiO}_{2}$, transmission remains below $0.5 \%$ for the entire UVB and UVA region, corresponding to a sun protection factor of SPF 100. To our knowledge, there has been no other studies who have produced or investigated sun protection patches. Most commercial sunscreens have SPF values of maximum 50+, but, as discussed in the introduction, this value is hugely user-dependent and may in practice be much lower if the sunscreen is not applied in sufficient amounts and at sufficient frequencies. As a comparison, the commercially available Mepiform silicone adhesive from Mölnlycke for scar prevention has an SPF value of 5[39].

What is more, it is also clear that storing $\mathrm{TiO}_{2}$-filled samples in ambient or high humidity conditions does not significantly increase light transmission. This is due to the high refractive index of $\mathrm{TiO}_{2}$, which means that, as the glycerol absorbs water under highly humid conditions, the refractive index of the silicone/ $/ \mathrm{TiO}_{2}$ phase is high enough to avoid refractive index matching between the two phases. Thus, adding $\mathrm{TiO}_{2}$ not only lowers light transmission and increases the SPF value of the glycerol/silicone patches, it also provides stable sun protection even after exposure to high moisture conditions. 


\section{$\sum_{3}^{\infty}$}

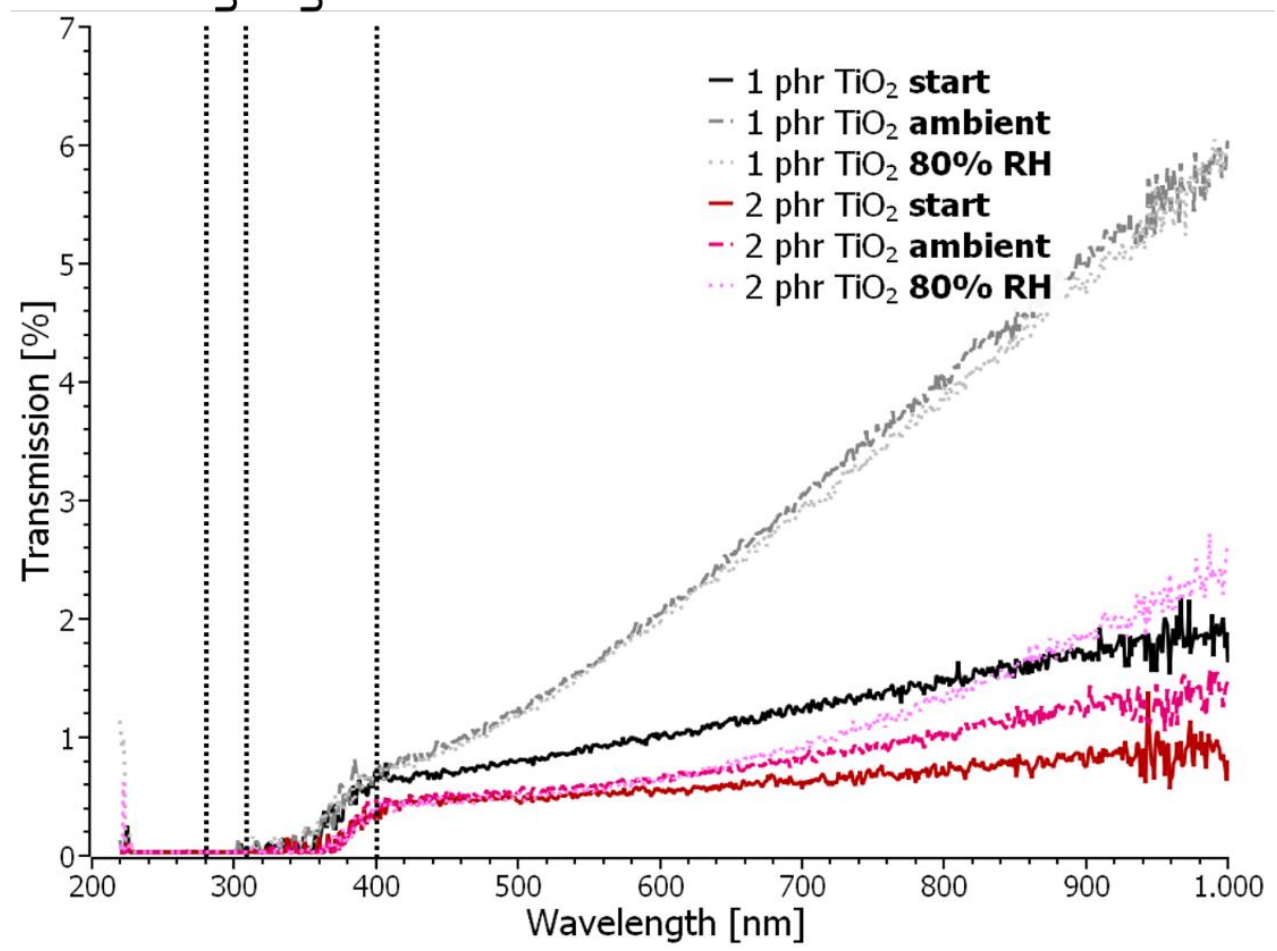

Figure 7: Transmission (\%) as a function of wavelength $(\mathrm{nm})$ for glycerol-filled silicone adhesives with $\mathrm{TiO}_{2}$ before and after storing at different conditions.

Table 4: Overview of the recorded transmission data for $60 \mathrm{phr}$ glycerol-filled silicone with 1 and $2 \mathrm{phr} \mathrm{TiO}_{2}$, respectively, on PU backing at various wavelengths, as well as the corresponding calculated SPF value.

\begin{tabular}{|c|c|c|c|c|c|c|c|}
\hline \multirow[b]{2}{*}{ Sample } & \multirow{2}{*}{$\begin{array}{c}\text { Time of } \\
\text { measurement }\end{array}$} & \multicolumn{5}{|c|}{ Transmission (\%) } & \multirow{2}{*}{$\begin{array}{l}\text { Calculated } \\
\text { SPF value }\end{array}$} \\
\hline & & $\begin{array}{c}280 \mathrm{~nm} \\
\left(T_{\min }\right)\end{array}$ & $300 \mathrm{~nm}$ & $\begin{array}{c}315 \mathrm{~nm} \\
\left(T_{\max }\right)\end{array}$ & $350 \mathrm{~nm}$ & $400 \mathrm{~nm}$ & \\
\hline \multirow{3}{*}{$\begin{array}{c}60 \text { phr } \\
\text { glycerol + } 1 \\
\text { phr } \mathrm{TiO}_{2}\end{array}$} & $\begin{array}{c}\text { Immediately after } \\
\text { curing (start) }\end{array}$ & 0,03 & 0,03 & 0,03 & 0,13 & 0,70 & 100 \\
\hline & $\begin{array}{c}20 \text { h @ ambient } \\
\text { conditions } \\
\text { (ambient) }\end{array}$ & 0,03 & 0,03 & 0,12 & 0,10 & 0,71 & 99 \\
\hline & $\begin{array}{c}20 \mathrm{~h} @ 80 \% \mathrm{RH} \\
(80 \% \mathrm{RH})\end{array}$ & 0,03 & 0,03 & 0,03 & 0,26 & 0,71 & 98 \\
\hline \multirow{3}{*}{$\begin{array}{c}60 \mathrm{phr} \\
\text { glycerol + } 2 \\
\text { phr } \mathrm{TiO}_{2}\end{array}$} & $\begin{array}{c}\text { Immediately after } \\
\text { curing (start) }\end{array}$ & 0,03 & 0,03 & 0,03 & 0,11 & 0,38 & 100 \\
\hline & $\begin{array}{c}20 \mathrm{~h} @ \text { ambient } \\
\text { conditions } \\
\text { (ambient) }\end{array}$ & 0,03 & 0,03 & 0,03 & 0,03 & 0,48 & 100 \\
\hline & $\begin{array}{c}20 \mathrm{~h} @ 80 \% \mathrm{RH} \\
(80 \% \mathrm{RH})\end{array}$ & 0,03 & 0,03 & 0,03 & 0,03 & 0,41 & 100 \\
\hline
\end{tabular}




\section{Conclusion}

In this study, a glycerol-silicone adhesive patch with inherent sun protection was successfully prepared from stable two-phase systems in which silicone constitutes the continuous phase and glycerol exists as discrete droplets in the cured silicone matrix. The sun protection properties of the glycerol-filled silicone adhesives were found to increase with increasing glycerol content, reaching a sun protection factor (SPF) of 49 for an adhesive with $60 \mathrm{phr}$ glycerol. However, sun protection-i.e., the ability to block UV light transmission - was found to be negatively affected by moisture, as glycerol is highly hygroscopic and silicone is permeable to water vapor. Light transmission increased upon storing for $20 \mathrm{~h}$ at $80 \%$ relative humidity, leading to a decrease in SPF-value to 37 for the $60 \mathrm{phr}$ glycerol adhesive due to the fact that water lowers the refractive index of glycerol, which then approaches that of silicone and allows the light to pass through the adhesive without being refracted. $\mathrm{TiO}_{2}$, a commonly used inorganic UV filter in sun protection products, was therefore added to decrease light transmission, thereby increasing the SPF of the $\mathrm{TiO}_{2}$-loaded $60 \mathrm{phr}$ adhesive patch to 100. Light transmission did not increase for adhesives with $\mathrm{TiO}_{2}$ upon exposure to moisture due to the high refractive index of $\mathrm{TiO}_{2}$, which is high enough to avoid refractive index matching between the two phases when glycerol absorbs water from the patch's surroundings. These findings, along with favorable mechanical and peel strength properties as well as attractive wound care properties, suggest that glycerol-filled silicone adhesives with $\mathrm{TiO}_{2}$ can be excellent sun protection patches for sensitive or broken skin.

\section{Acknowledgements}

Funding from Innovation Fund Denmark is highly appreciated. 


\section{References}

[1] C. Battie, S. Jitsukawa, F. Bernerd, S. Del Bino, C. Marionnet, and M. Verschoore, "New insights in photoaging, UVA induced damage and skin types," Exp. Dermatol., vol. 23, pp. 7-12, 2014.

[2] Solar and Ultraviolet Radiation IARC Monographs on the Evaluation of Carcinogenic Risks to Humans Volume 55. Lyon, France, 1992.

[3] R. Lucas, T. McMichael, W. Smith, and B. Armstrong, Solar Ultraviolet Radiation. 2006.

[4] Y. Chang, J. Newton-Bishop, and et al. Bishop DT, "A pooled analysis of melanocytic nevus phenotype and the risk of cutaneous melanoma at different latitudes," Int. J. Cancer, vol. 124, no. 2, pp. 420-428, 2009.

[5] C. M. Olsen et al., "Cancers in Australia attributable to exposure to solar ultraviolet radiation and prevented by regular sunscreen use," Aust. N. Z. J. Public Health, vol. 39, no. 5, pp. 471-476, 2015.

[6] B. K. Armstrong and A. Kricker, "The epidemiology of UV induced skin cancer," J. Photochem. Photobiol. B Biol., vol. 63, pp. 8-18, 2001.

[7] P. Perugini, M. Bonetti, A. C. Cozzi, and G. L. Colombo, "Topical Sunscreen Application Preventing Skin Cancer: Systematic Review," Cosmetics, vol. 6, no. 3, p. 42, 2019.

[8] D. R. Sambandan and D. Ratner, "Sunscreens: An overview and update," J. Am. Acad. Dermatol., vol. 64, no. 4, pp. 748-758, 2011.

[9] N. A. Shaath, "Ultraviolet filters," Photochem. Photobiol. Sci., vol. 9, pp. 464-469, 2010.

[10] Ngoc, Tran, Moon, Chae, Park, and Lee, "Recent Trends of Sunscreen Cosmetic: An Update Review," Cosmetics, vol. 6, no. 4, p. 64, 2019, doi: 10.3390/cosmetics6040064.

[11] C. Cole, T. Shyr, and H. Ou-Yang, "Metal oxide sunscreens protect skin by absorption, not by reflection or scattering," Photodermatol. Photoimmunol. Photomed., vol. 32, no. 1, pp. 5-10, 2016, doi: 10.1111/phpp.12214.

[12] A. P. Popov, A. V. Priezzhev, J. Lademann, and R. Myllylä, "TiO2 nanoparticles as an effective UV-B radiation skin-protective compound in sunscreens," J. Phys. D. Appl. Phys., vol. 38, no. 15, pp. 25642570, 2005, doi: 10.1088/0022-3727/38/15/006.

[13] J. Finlay-Jones and P. H. Hart, "Photoprotection: sunscreens and the immunomodulatory effects of UV irradiation," Mutat. Res. Mol. Mech. Mutagen., vol. 422, no. 1, pp. 155-159, 1998.

[14] U. Osterwalder and B. Herzog, "Sun protection factors: World wide confusion," Br. J. Dermatol., vol. 161, no. SUPPL. 3, pp. 13-24, 2009.

[15] Commission Recommendation of 22 September 2006 on the efficacy of sunscreen products and the claims made relating thereto (notified under document number C(2006) 4089) (Text with EEA relevance). .

[16] E. A. Dutra, D. A. G. Da Costa E Oliveira, E. R. M. Kedor-Hackmann, and M. I. R. Miritello Santoro, "Determination of sun protection factor (SPF) of sunscreens by ultraviolet spectrophotometry," Rev. Bras. Ciencias Farm. J. Pharm. Sci., vol. 40, no. 3, pp. 381-385, 2004.

[17] T. Teramura, M. Mizuno, H. Asano, N. Naito, K. Arakane, and Y. Miyachi, "Relationship between sunprotection factor and application thickness in high-performance sunscreen: double application of sunscreen is recommended," Clin. Exp. Dermatol., vol. 37, no. 8, pp. 904-908, 2012. 
[18] A. Fonseca and R. Fonseca, "Determination Of Sun Protection Factor By Uv-Vis Spectrophotometry Health Care: Current Reviews," Heal. Care Curr. Rev., vol. 1, p. 1, 2013.

[19] B. P. Binks, P. D. I. Fletcher, A. J. Johnson, I. Marinopoulos, J. Crowther, and M. A. Thompson, "How the sun protection factor (SPF) of sunscreen films change during solar irradiation," J. Photochem. Photobiol. A Chem., vol. 333, pp. 186-199, 2017, doi: 10.1016/j.jphotochem.2016.10.027.

[20] S. S. Mali and S. G. Killedar, "Formulation and in vitro evaluation of gel for SPF determination and free radical scavenging activity of turpentine and lavender oil," Pharma Innov. J., vol. 7, no. 3, pp. 85-90, 2018.

[21] J. S. Mansur, M. N. R. Breder, and M. C. A. Mansur, "DETERMINACAO DO FATOR DE PROTECAO SOLAR POR ESPECTROFOTOMETRIA," An. Bras. Dermatol., vol. 61, no. 3, pp. 121-124, 1986.

[22] R. M. Sayre, P. P. Agin, G. J. LeVee, and E. Marlowe, "A comparison of in vivo and in vitro testing of sunscreening formulas," Photochem. Photobiol., vol. 29, pp. 559-566, 1979, doi: 10.1016/S05809517(06)36020-5.

[23] P. Mazurek, S. Hvilsted, and A. L. Skov, "Green silicone elastomer obtained from a counterintuitively stable mixture of glycerol and PDMS," Polymer (Guildf)., vol. 87, pp. 1-7, 2016.

[24] P. Mazurek, M. A. Brook, and A. L. Skov, "Glycerol-Silicone Elastomers as Active Matrices with Controllable Release Profiles," Langmuir, vol. 34, no. 38, pp. 11559-11566, 2018.

[25] P. Mazurek, B. E. F. Ekbrant, F. B. Madsen, L. Yu, and A. L. Skov, "Glycerol-silicone foams - Tunable 3phase elastomeric porous materials," Eur. Polym. J., vol. 113, 2019.

[26] V. Chiaula, P. Mazurek, J. Eiler, A. C. Nielsen, and A. L. Skov, "Glycerol-silicone adhesives with excellent fluid handling and mechanical properties for advanced wound care applications," Int. J. Adhes. Adhes., vol. 102, no. June, p. 102667, 2020.

[27] P. S. Murphy and G. R. D. Evans, "Review Article Advances in Wound Healing: A Review of Current Wound Healing Products," vol. 2012, 2012, doi: 10.1155/2012/190436.

[28] A. J. O'Lenick Jr., Silicones for Personal Care, 2nd Editio. Allured Piblishing Corporation, 2008.

[29] R. Winter, A Consumer's Dictionary of Cosmetic Ingredients, 7th Editio. Three River Press, 2009.

[30] B. Bleasdale, S. Finnegan, K. Murray, S. Kelly, and S. L. Percival, "The Use of Silicone Adhesives for Scar Reduction," doi: 10.1089/wound.2015.0625.

[31] V. Chiaula, J. Madsen, P. Mazurek, A. C. Nielsen, and A. L. Skov, "Novel Antimicrobial GlycerolSilicone Adhesives Releasing Octenidine Incorporated via Cyclodextrins."

[32] J. D. Eshelby, "The determination of the elastic field of an ellipsoidal inclusion, and related problems," Proc. R. Soc. Lond. A. Math. Phys. Sci., vol. 241, no. 1226, pp. 376-396, 1957.

[33] M. K. Jensen, A. Bach, O. Hassager, and A. L. Skov, "Linear rheology of cross-linked polypropylene oxide as a pressure sensitive adhesive," Adhesives, vol. 29, no. 7, pp. 687-693, 2009.

[34] W. A. Chemie, "HEALTHCARE I MEDICAL ADHESIVES MEDICAL SILICONE ADHESIVES."

[35] D. C. C. Lam, F. Yang, and P. Tong, "Chemical Kinetic Model of Interfacial Degradation of Adhesive Joints," vol. 22, no. 2, pp. 215-220, 1999.

[36] L. Liu, K. Kuffel, D. K. Scott, G. Constantinescu, H. J. Chung, and J. Rieger, "Silicone-based adhesives for long-term skin application: Cleaning protocols and their effect on peel strength," Biomed. Phys. 
Eng. Express, vol. 4, no. 1, p. 015004, 2018, doi: 10.1088/2057-1976/aa91fb.

[37] B. Herzog, "Prediction of sun protection factors by calculation of transmissions with a calibrated step film model," J. Cosmet. Sci., vol. January, pp. 11-26, 2002.

[38] SCCS/1617/20 Final Opinion OPINION on Titanium dioxide $\left(\mathrm{TiO}_{2}\right)$ used in cosmetic products that lead to exposure by inhalation, 2020

[39] "Mepiform, Selvklæbende bandage til arbehandling." https://www.molnlycke.dk/SysSiteAssets/master-and-local markets/documents/denmark/wound/mepiform-pb-dk.pdf (accessed Sep. 29, 2020). 
Supporting information

Glycerol-filled silicone adhesive patches with excellent sun protection

Liyun Yu ${ }^{1}$, Piotr Mazurek ${ }^{1}$, Frederikke Bahrt Madsen², and Anne Ladegaard Skov ${ }^{1,2}$

${ }^{1}$ Danish Polymer Centre, Department of Chemical and Biochemical Engineering, Building 227, Technical University of Denmark, DK-2800 Kgs. Lyngby, Denmark

${ }^{2}$ Glysious Polymer Technologies, Futurebox, Elektrovej 331, 2800 Kongens Lyngby, Denmark

Sample appearance:
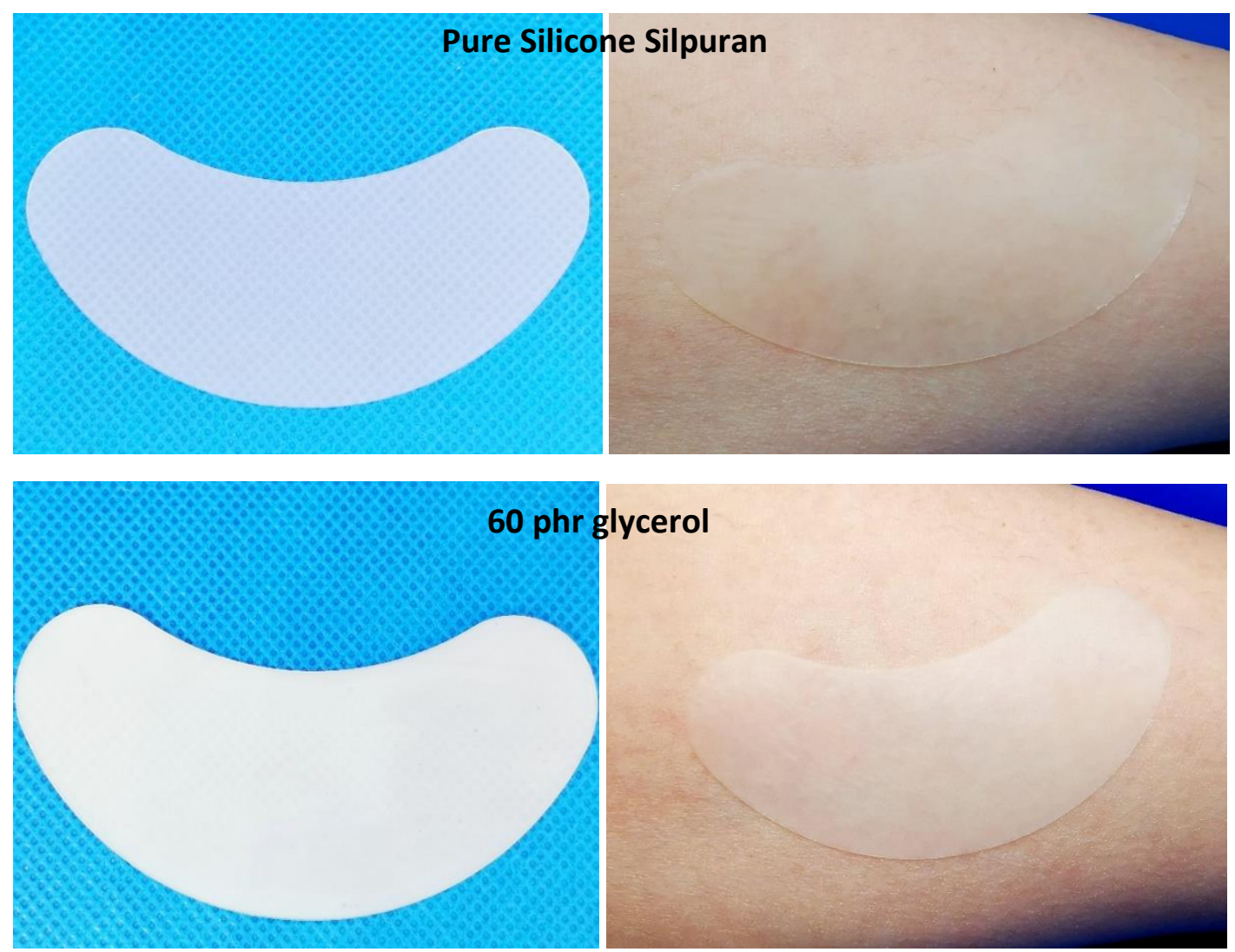

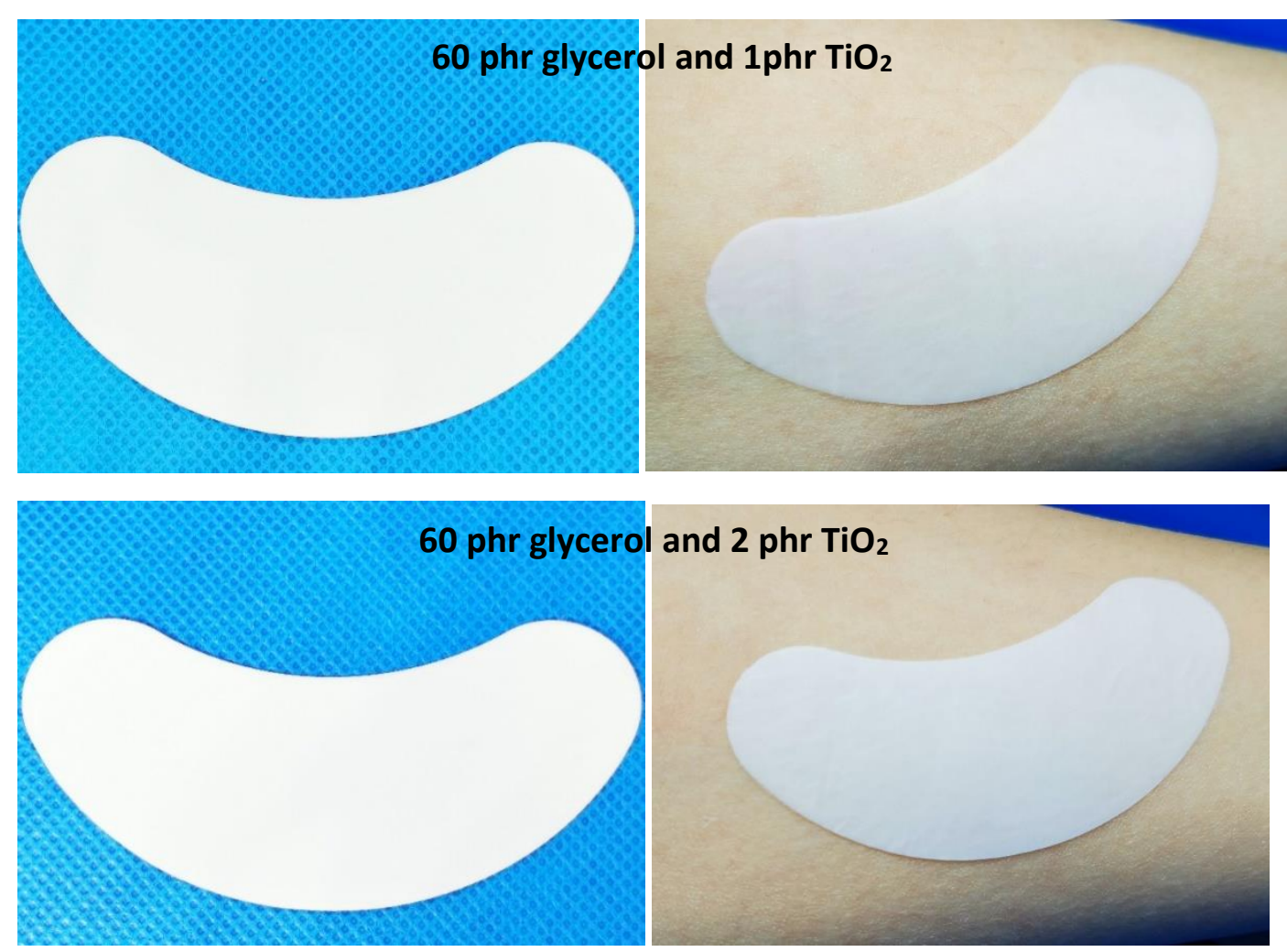


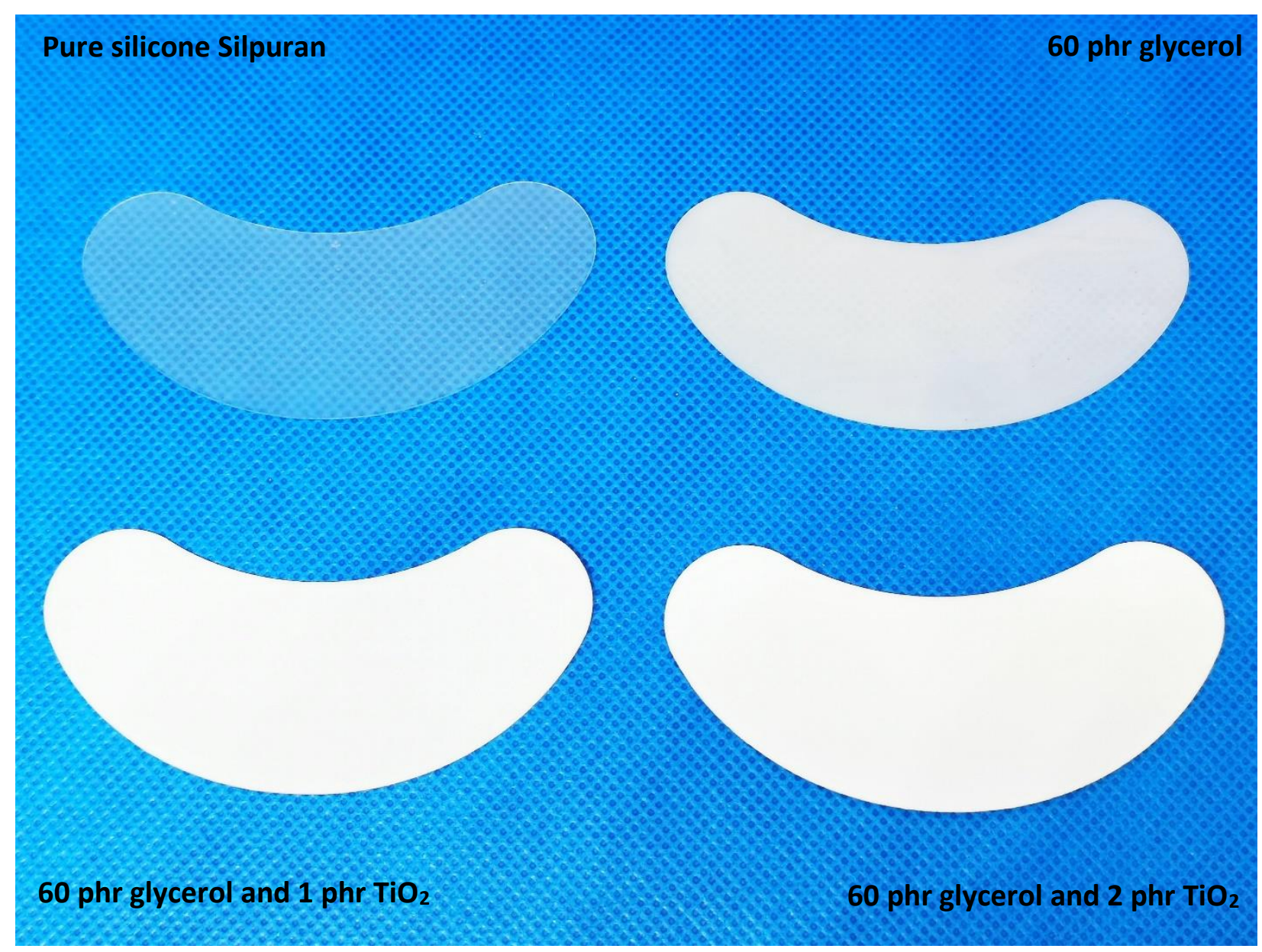

Figure S1: The appearance of adhesives with varying amounts of glycerol and $\mathrm{TiO}_{2}$. 
LVE:
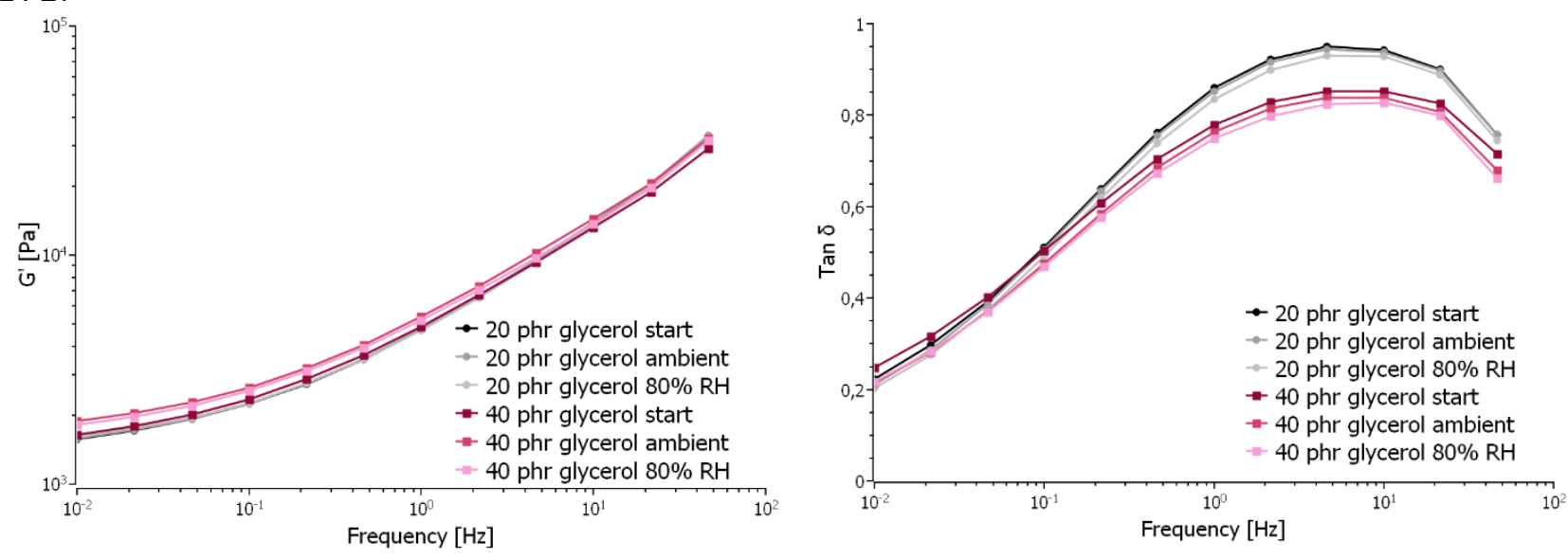

Figure S2: Linear viscoelastic properties of glycerol-filled silicone adhesives with varying content of glycerol before and after storing at ambient and high humidity conditions.

Transmission:

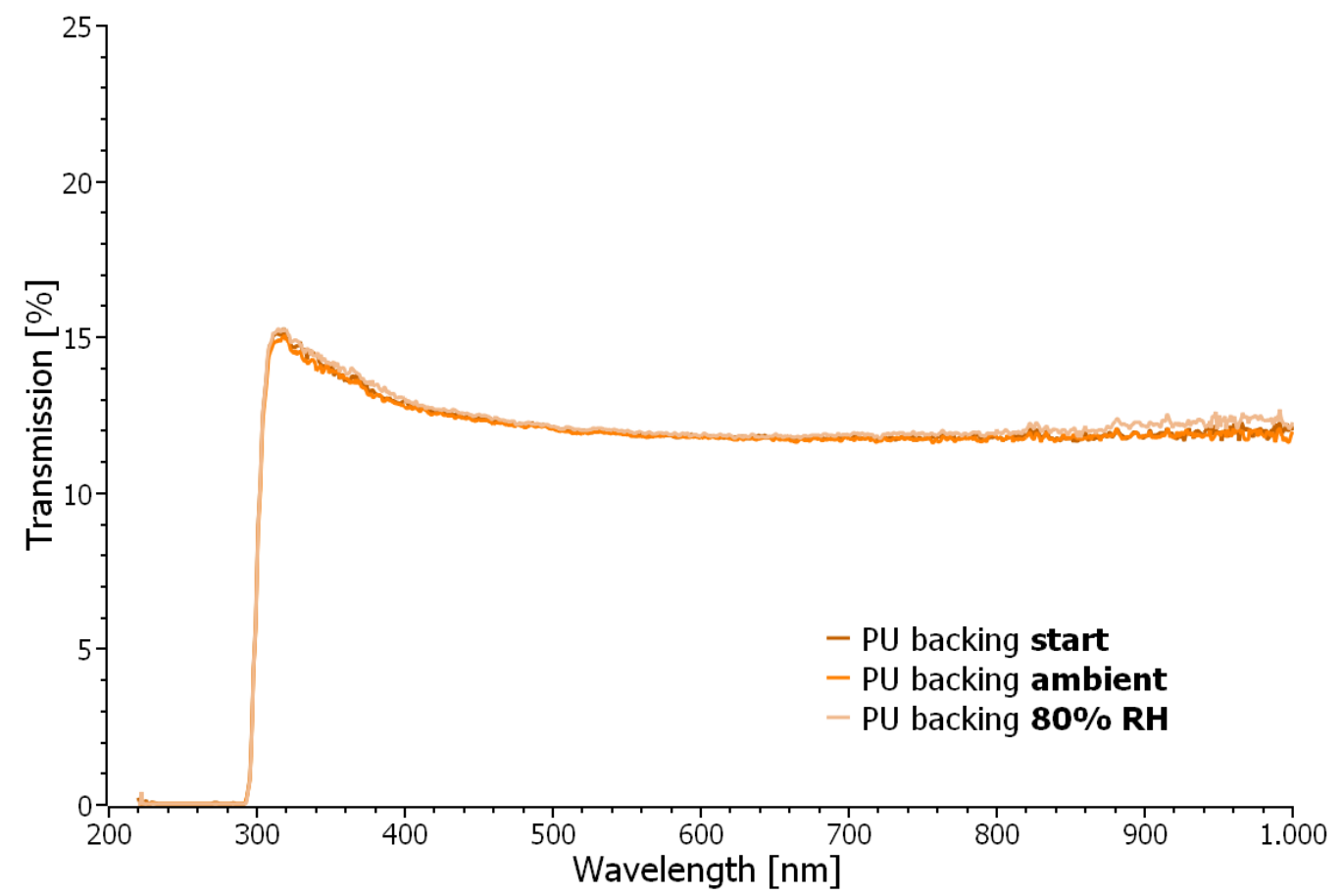

Figure S3: Transmission (\%) as function of wavelength $(\mathrm{nm})$ for PU backing with varying storing conditions. 


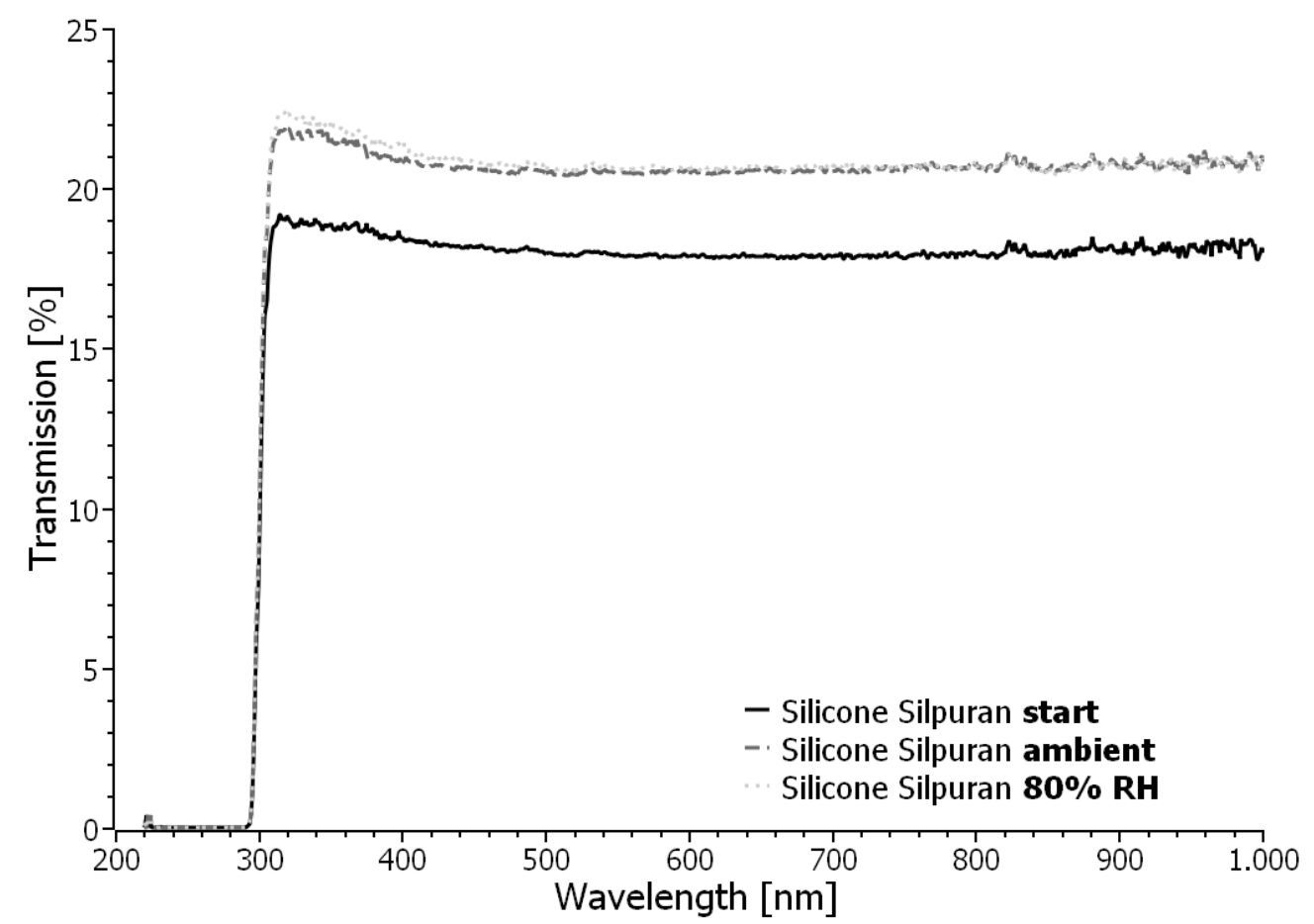

Figure S4: Transmission (\%) as function of wavelength $(\mathrm{nm})$ for pure silicone Silpuran adhesive with varying storing conditions.

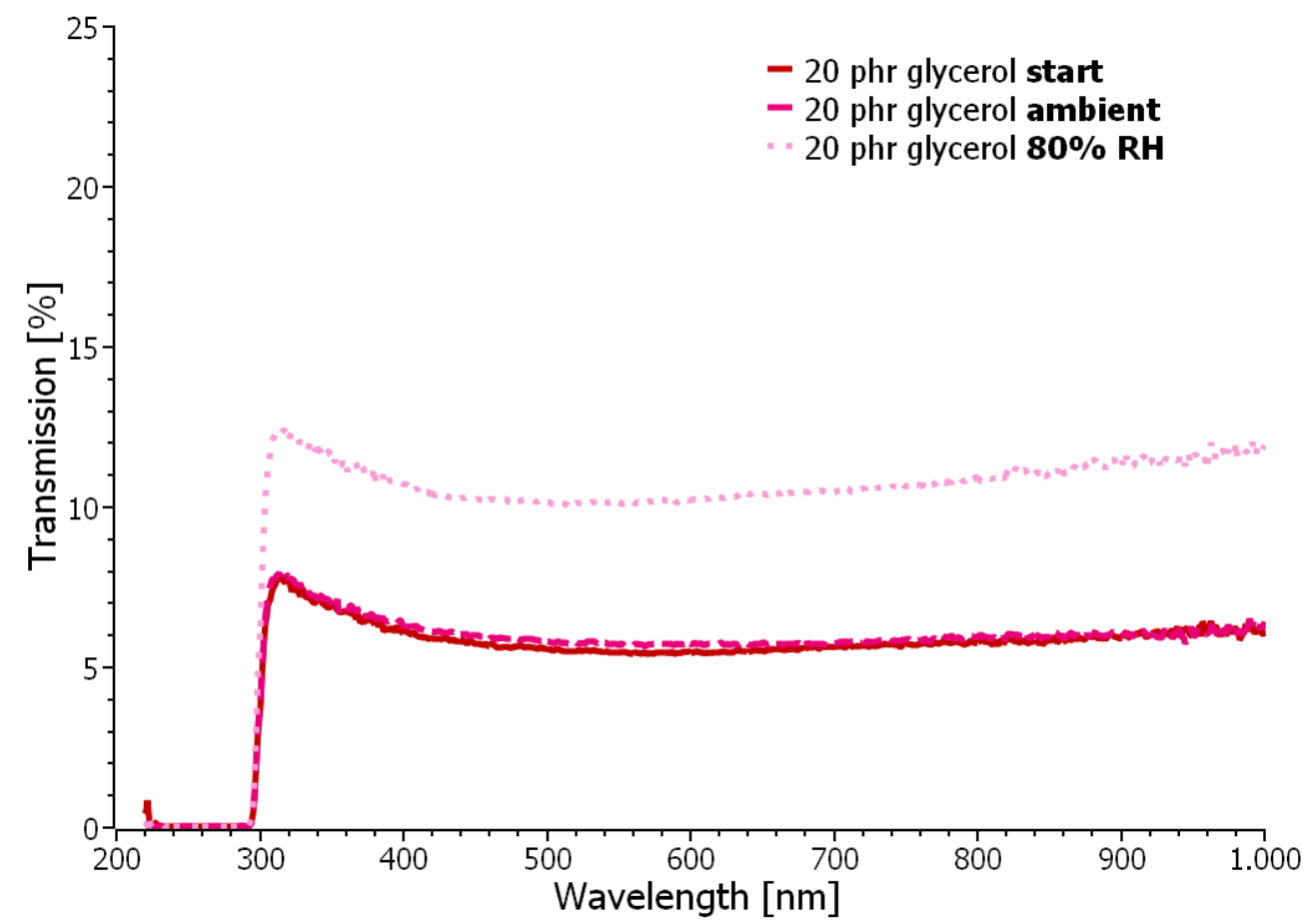

Figure S5: Transmission (\%) as function of wavelength $(\mathrm{nm})$ for 20 phr glycerol-filled silicone adhesive with varying storing conditions. 


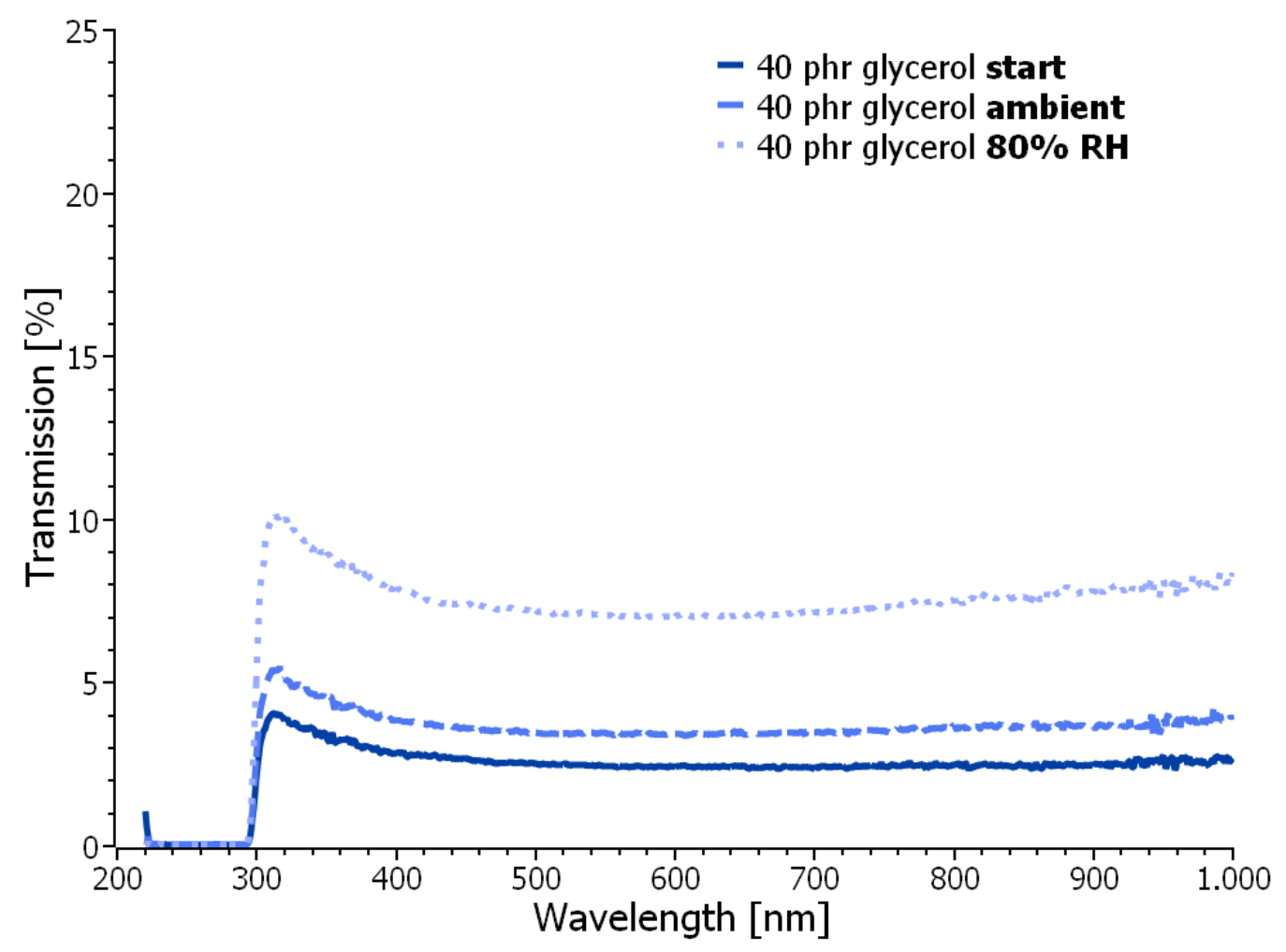

Figure S6: Transmission (\%) as function of wavelength $(\mathrm{nm})$ for 40 phr glycerol-filled silicone adhesive with varying storing conditions.

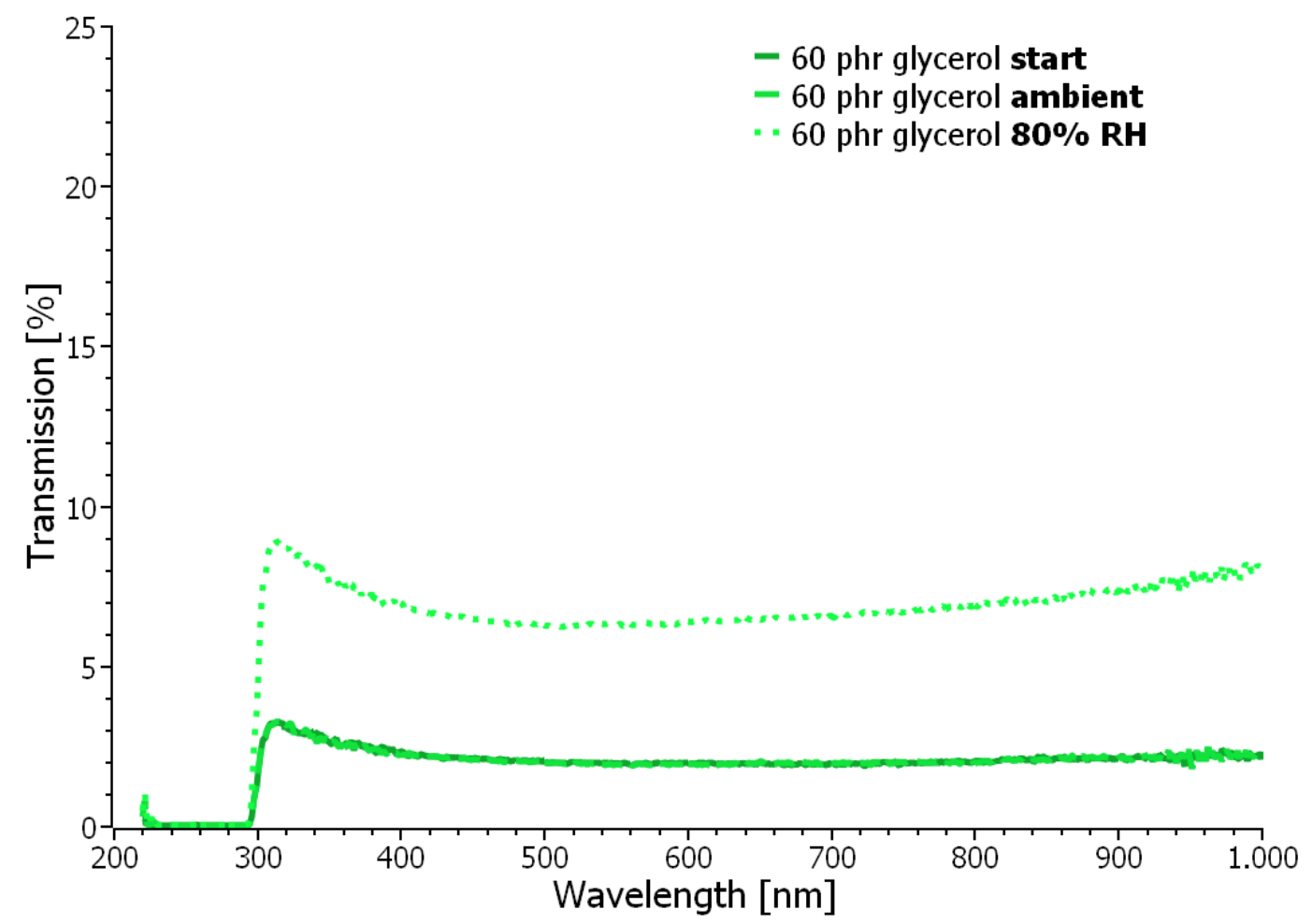

Figure S7: Transmission (\%) as function of wavelength $(\mathrm{nm})$ for 60 phr glycerol-filled silicone adhesive with varying storing conditions. 
SPF calculations:

The Mansur equation [21] was used to calculate the SPF values:

$\mathrm{SPF}=\mathrm{CF} \times \sum_{290}^{320} \mathrm{EE}(\lambda) \times \mathrm{I}(\lambda) \times \operatorname{Abs}(\lambda)$

Where EE ( $\lambda)$ : Erythemal effect spectrum; I $(\lambda)$ : Solar intensity spectrum; Abs $(\lambda)$ : Absorbance of sunscreen product; CF: Correction factor $(=10)$. The value of $E E(\lambda) \times I(\lambda)$ are a constant which was determined by Sayre et al. [22].

The maximum absorbance value of the utilized POLARstar Omega spectrometer is 3.5 as shown in Figure s7.

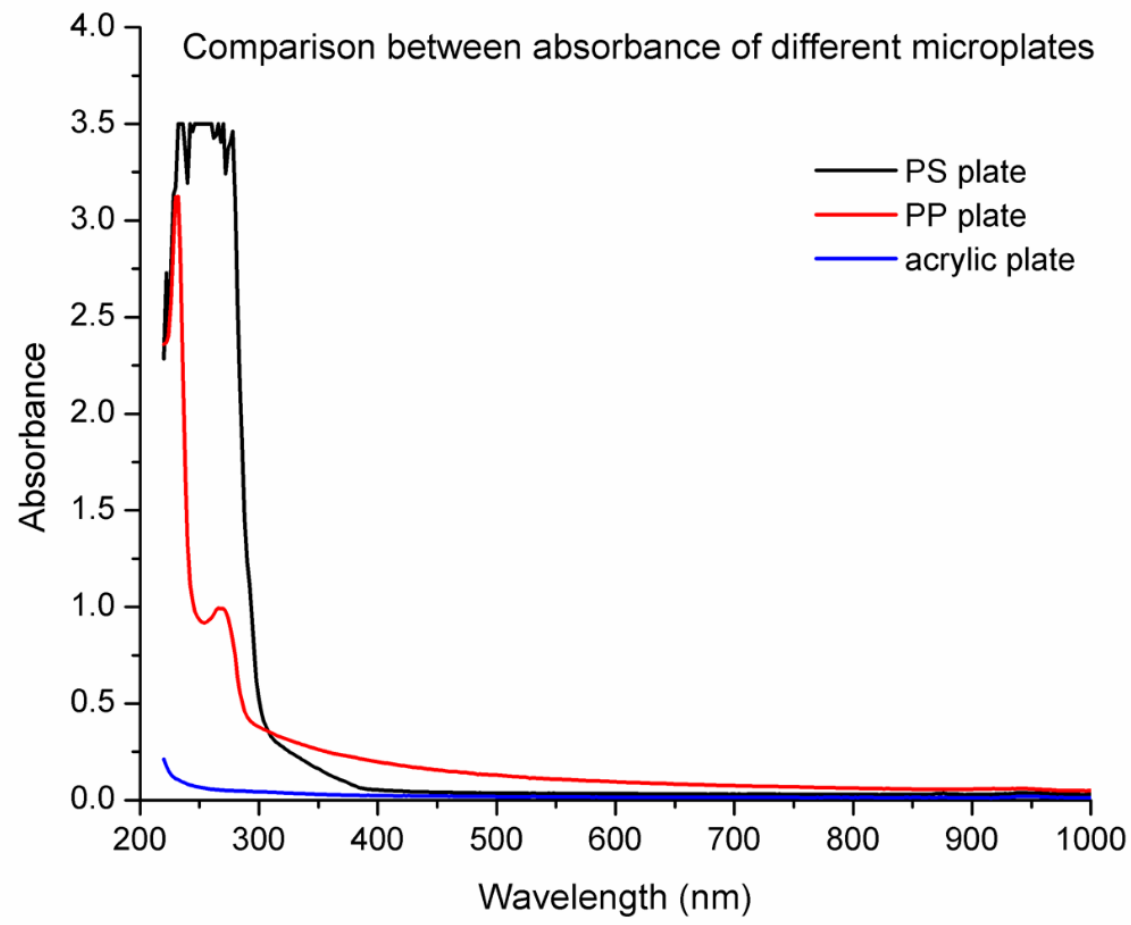

Figure S8: Image of $m$ absorbance of POLARstar Omega spectrometer as function of wavelength (nm).

Therefore the correction factor was normalized to yield: $\mathrm{CF}^{*}=(100 / 35) * 10=28.57$. 
SEM:

Scanning electron microscopy was performed on samples containing $\mathrm{TiO}_{2}$ in order to investigate their crosssectional morphology. The soft nature of the medical grade SILPURAN ${ }^{\circledR} 2130$ A/B silicone, however, leads to a collapse of the glycerol-droplets during the high vacuum conditions in the sputter coater and SEM chamber. Therefore, a more rigid glycerol-filled silicone adhesive based on SYLGARD 184 from DOW is also presented in order to illustrate the morphology of a non-collapsed glycerol-droplet structure.
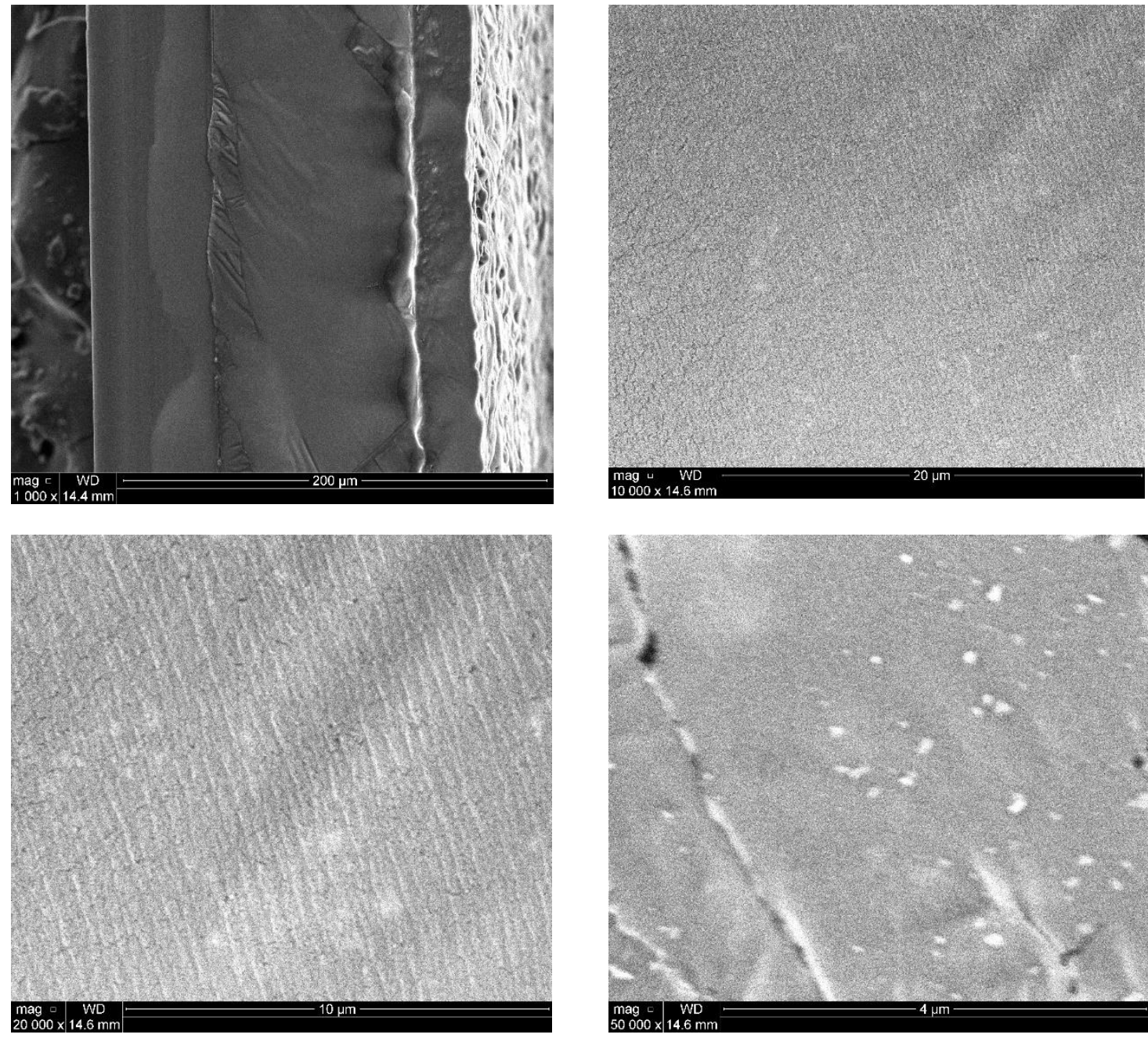

Figure S9: SEM images of glycerol-silicone adhesive with $60 \mathrm{phr}$ glycerol and $1 \mathrm{phr} \mathrm{TiO}_{2}$ at different magnification levels. 

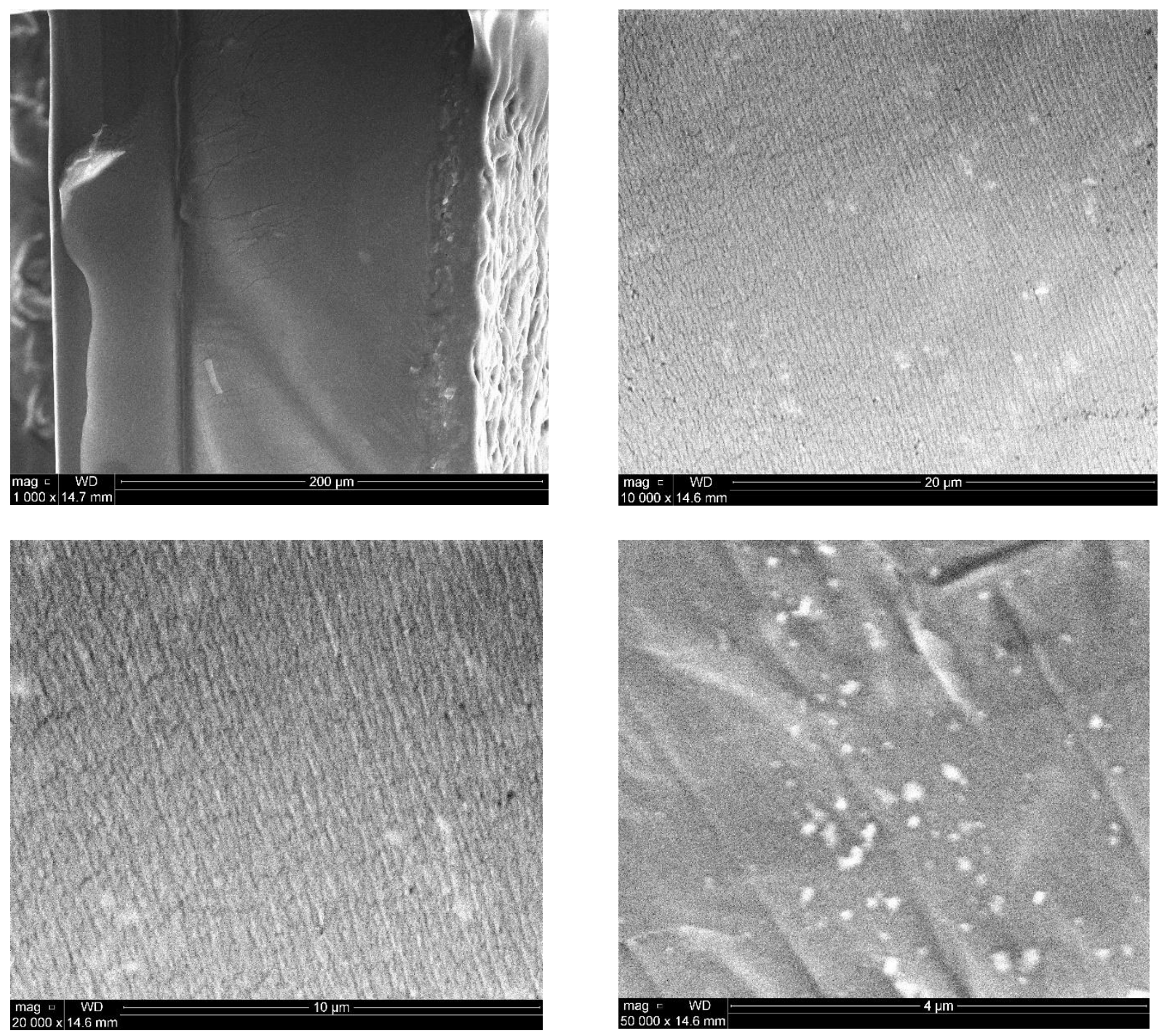

Figure S10: SEM images of glycerol-silicone adhesive with $60 \mathrm{phr}$ glycerol and $1 \mathrm{phr} \mathrm{TiO}_{2}$ at different magnification levels.
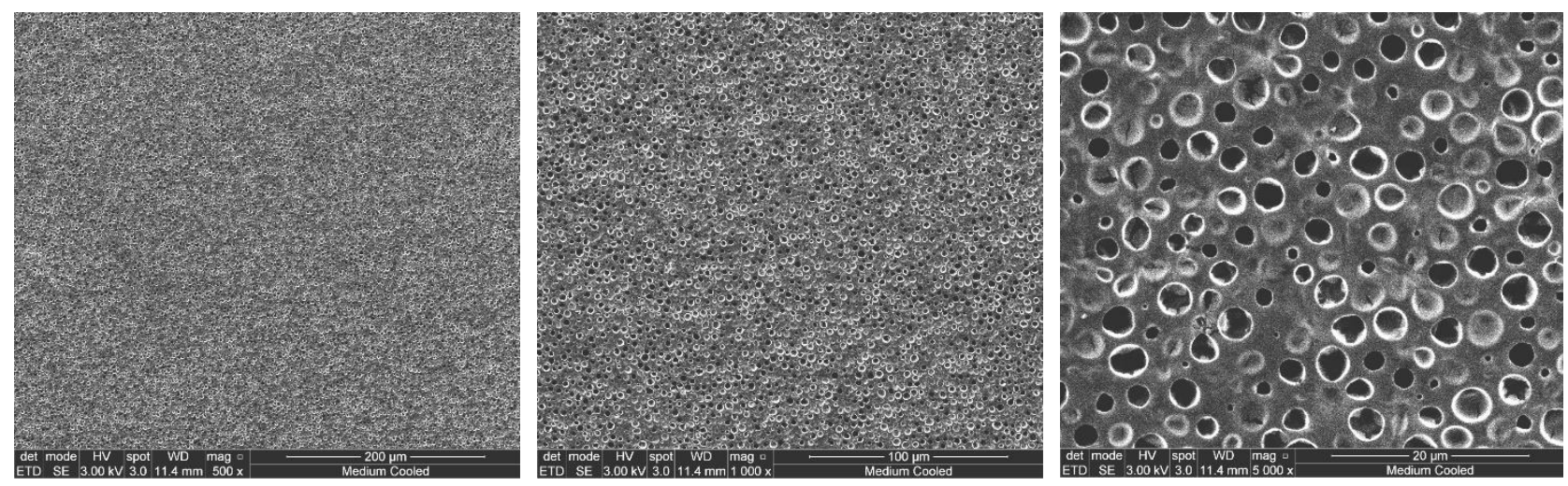

Figure S11: SEM images of glycerol-silicone adhesive based on SYLGARD 184 and 60 phr glycerol at different magnification levels. 
Optical microscopy images:

Optical microscopy was performed on samples containing $\mathrm{TiO}_{2}$ in order to investigate their morphology. The $\mathrm{TiO}_{2}$-particles are seen as small white spots. The larger spheres are glycerol-droplets.
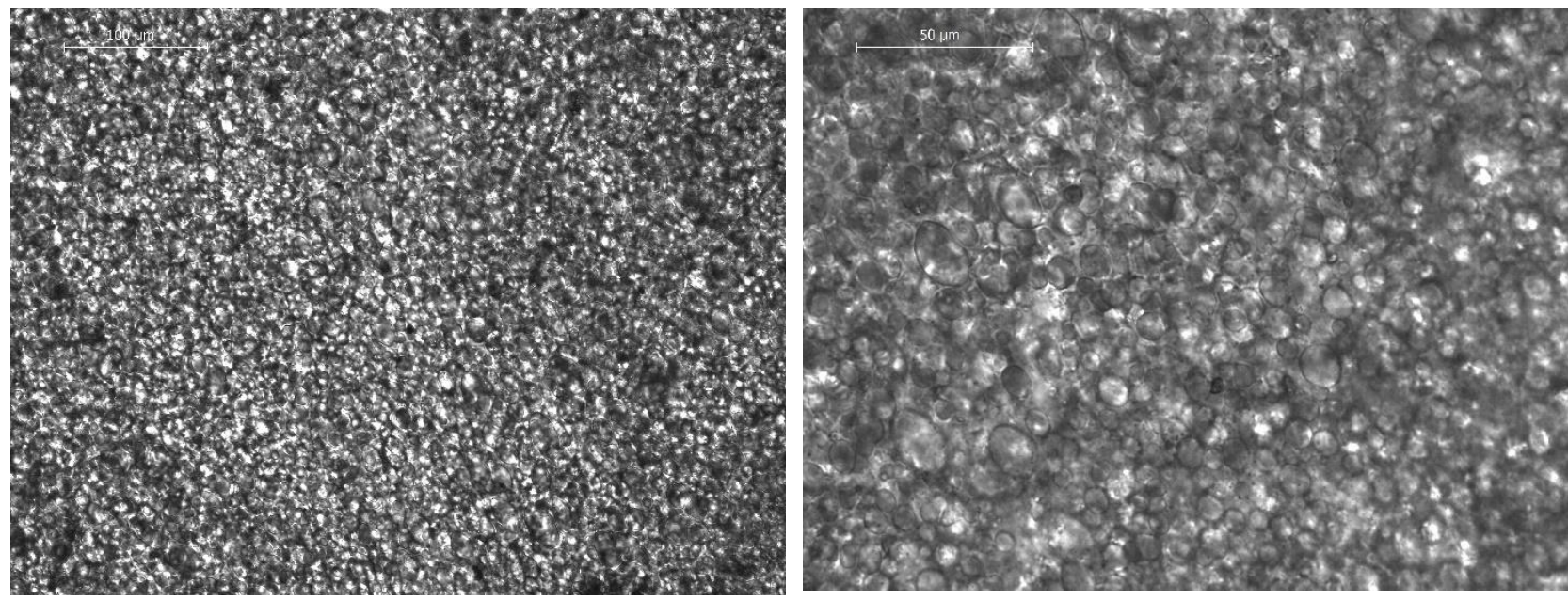

Figure S12: Optical microscopy images of glycerol-silicone adhesive with $60 \mathrm{phr}$ glycerol and $1 \mathrm{phr} \mathrm{TiO}_{2}$ at different magnification levels.
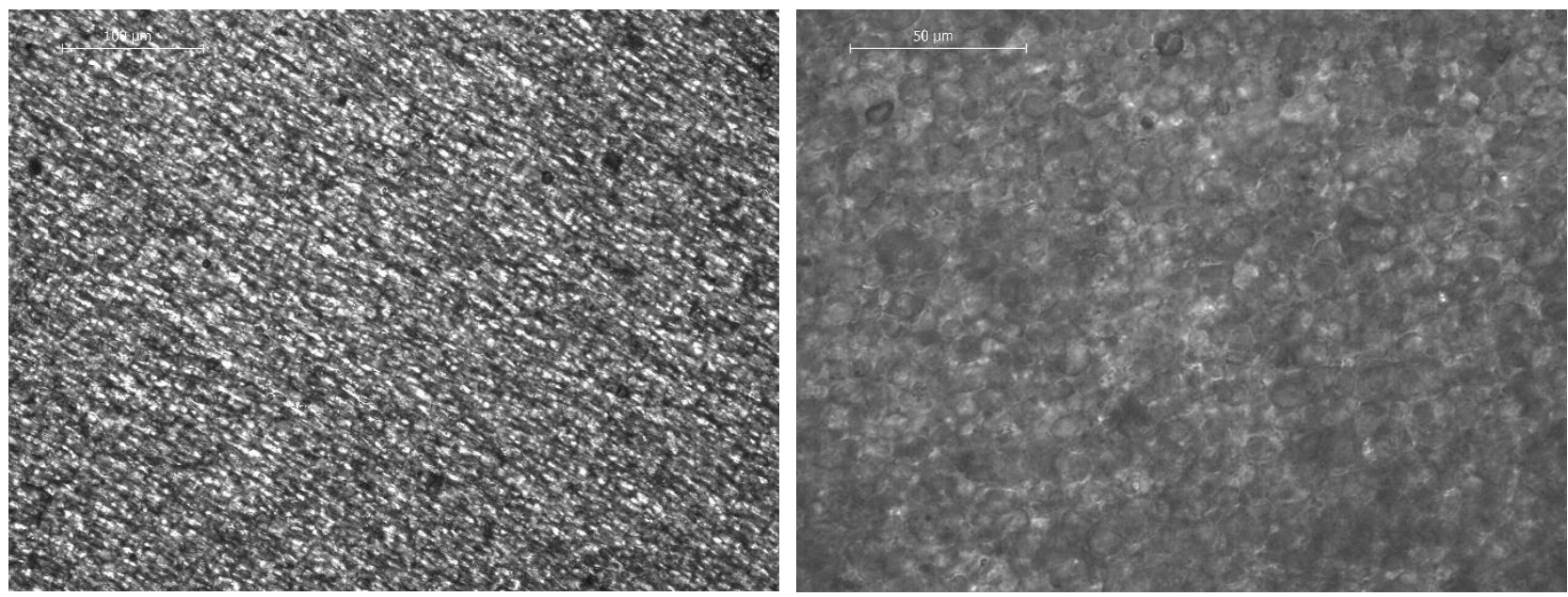

Figure S13: Optical microscopy images of glycerol-silicone adhesive with $60 \mathrm{phr}$ glycerol and 2 phr $\mathrm{TiO}_{2}$ at different magnification levels. 


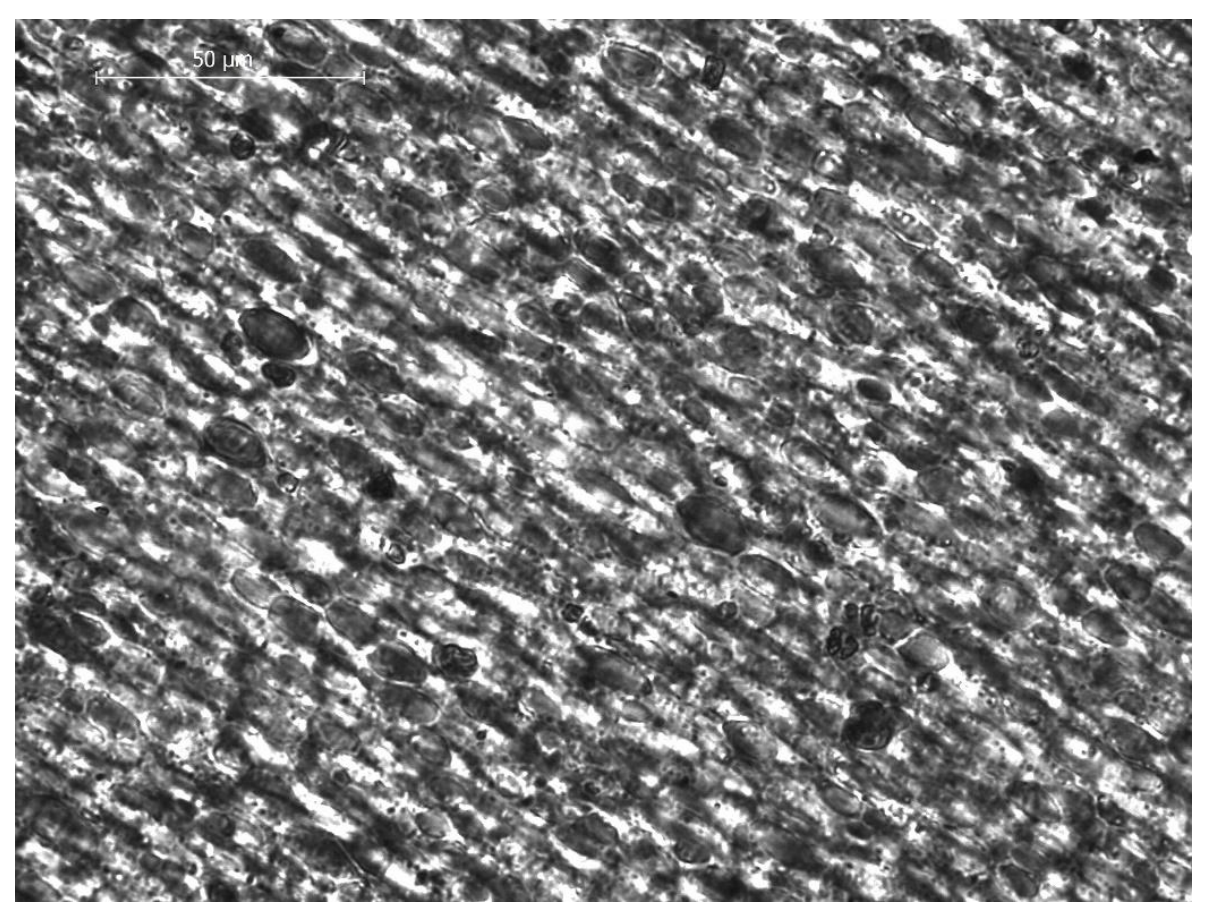

Figure S14: Optical microscopy images of glycerol-silicone adhesive with $60 \mathrm{phr}$ glycerol and 2 phr TiO 2 which has been stretched slightly in order to enhance the appearance of the glycerol-droplet structures within the silicone. 